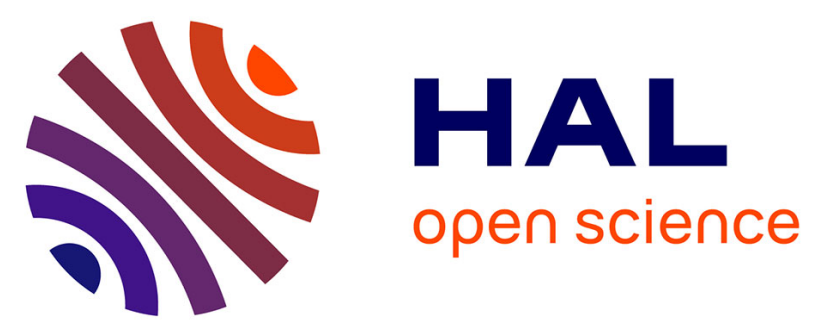

\title{
Exhumation history of the Variscan orogen in western Iberia as inferred from new K-Ar and 40Ar/39Ar data on granites from Portugal
}

\author{
A. Hildenbrand, F.O. Marques, X. Quidelleur, F. Noronha
}

\section{- To cite this version:}

A. Hildenbrand, F.O. Marques, X. Quidelleur, F. Noronha. Exhumation history of the Variscan orogen in western Iberia as inferred from new K-Ar and $40 \mathrm{Ar} / 39 \mathrm{Ar}$ data on granites from Portugal. Tectonophysics, 2021, 812, pp.228863. 10.1016/j.tecto.2021.228863 . hal-03398810

\author{
HAL Id: hal-03398810 \\ https://hal.science/hal-03398810
}

Submitted on 23 Oct 2021

HAL is a multi-disciplinary open access archive for the deposit and dissemination of scientific research documents, whether they are published or not. The documents may come from teaching and research institutions in France or abroad, or from public or private research centers.
L'archive ouverte pluridisciplinaire HAL, est destinée au dépôt et à la diffusion de documents scientifiques de niveau recherche, publiés ou non, émanant des établissements d'enseignement et de recherche français ou étrangers, des laboratoires publics ou privés. 


\section{Exhumation history of the Variscan orogen in western Iberia}


Abstract

Exhumation of the roots of collapsing orogens is a key process in the evolution of mountain belts, which is critical for the understanding of orogenic cycles. From new structural analyses, K-Ar and ${ }^{40} \mathrm{Ar} /{ }^{39} \mathrm{Ar}$ on muscovite, biotite and $\mathrm{K}$-feldspar, and available U-Pb ages, we constrain the cooling and exhumation history of granitic batholiths from the main structural zones of the Variscan orogen in Iberia. We show that: (1) the oldest Ar dated granites (ca. $335 \mathrm{Ma}$ on biotite) record exhumation of gneisses crystallized much earlier (up to ca. 530-510 Ma U-Pb age); (2) granitoids crystallized at ca. $330 \mathrm{Ma}$ record mostly ductile stretching (L-tectonites striking around N-S), consistent with N-S extension (Variscan intra-orogenic collapse); (3) most granites crystallized between ca. 320 and 305 Ma record ductile stretching consistent with deformation along NW-SE to ENE-WSW shear zones during the late-Variscan compression (C3); (4) granites crystallized after $305 \mathrm{Ma}$ record mostly isotropic strain (no visible ductile foliation or lineation), consistent with their emplacement during/after the final collapse of the Variscan orogeny (E2); (5) comparison between Ar ages on micas and zircon U-Pb ages shows two contrasting situations: (i) similar ages, reflecting crystallization and fast cooling, which can be explained by relatively shallow intrusion and/or fast tectonic uplift; (ii) significant difference between $\mathrm{U}-\mathrm{Pb}$ and Ar ages, supporting crystallization of deeper seated intrusions and their subsequent uplift for several Ma to tens of $\mathrm{Ma}$; (6) thermochronological modelling on K-feldspar supports significant tectonic exhumation in the core of the chain between ca. 315 and $285 \mathrm{Ma}$, followed by late-stage passive denudation; 7) Late Carboniferous to early Permian tectonic exhumation was accompanied by significant formation of ore-deposits. Tin deposits occur in pegmatites and/or quartz veins associated with muscovite-rich syn-C3 granites and those of tungsten in quartz veins, breccia pipes and skarns associated with the E2 biotite-rich granites.

Keywords: Variscan orogeny, western Iberia; ${ }^{40} \mathrm{Ar} /{ }^{39} \mathrm{Ar}$ and $\mathrm{K}$-Ar dating; ${ }^{40} \mathrm{Ar}{ }^{\beta 9} \mathrm{Ar}$ 


\section{Introduction}

The formation of mountain belts involves episodes of granitization at various scales and depths, which contribute to the incremental growth and evolution of the Earth's continental crust (e.g., Hawkesworth et al., 2019). At some point during, between or after the main building stages, orogens may become gravitationally unstable and may experience collapse (e.g., Burg et al., 1994; Rey et al., 2001), denudation, and isostatic rebound, leading to the exhumation of their granitic roots. During the last 20 years, the links between orogenic collapse and crustal exhumation have been extensively investigated through geological, geochronological, and modelling approaches (Vanderhaeghe and Teyssier, 2001; Jadamec et al., 2007; Gerbault et al., 2018; Chardon et al., 2020 and references therein). Some studies have tested the effects of variable viscosity and density of the deep crust during lithospheric extension and identified contrasted modes of exhumation with uplift rates reaching $\mathrm{km} / \mathrm{Myr}$ (e.g., Korchinsky et al., 2018). Others have studied the influence of in-situ radiogenic heating, shearing, and partial melt generation and migration, which may modify the thermal and mechanical properties of the crust, favouring rapid exhumation, even during ongoing compression (e.g., Gerbault et al., 2018). Nevertheless, the timing and rates of exhumation associated with either collapse tectonics or late denudation by erosion remain, in many cases, insufficiently documented, despite being critical to the understanding of orogenic cycles and ore-deposit formation.

Since the early nineteen forties, geochronological methods based on the natural decay of radioactive elements have been extensively developed to solve a number of problems in Earth Sciences (e.g., Nier et al., 1941; Holmes, 1946; Houtermans, 1946; Roth and Poty, 1985). In the case of old felsic rocks such as granites, the Rb-Sr and U-Pb methods have been widely used to constrain the age of magma production and crystallization at depth. U-Pb on zircon is an especially powerful approach, as the refractory behaviour of this mineral hampers 
resetting of the chronometer at high temperature, up to ca. $900{ }^{\circ} \mathrm{C}$ (e.g., Lee et al., 1997; Cherniak and Watson, 2000). While monazite may be sensitive to partial U-Pb age resetting in the presence of hot fluids (e.g., Tartese et al., 2011), magmatic zircons generally keep the memory of various stages of crystallization. These stages can sometimes be resolved at the scale of a single mineral grain through laser-ablation and high-sensitivity ion-probe in-situ measurements of various crystal growths (e.g. Ireland et al., 2008). However, due to its high closure temperature, zircon U-Pb dating does not allow the reconstruction of the cooling history below ca. $900{ }^{\circ} \mathrm{C}$. Therefore, U-Pb on zircon has been used extensively to constrain successive stages of granite crystallization worldwide. However, it is not suitable to interpret cooling associated with the late-stage collapse and exhumation of mountain belts such as the Variscan orogen in western Iberia.

One way to constrain exhumation rates is to reconstruct the thermal history of batholiths exhumed to the surface by late orogenic isostatic rebound and denudation and compare the differential behaviour of the various portions of an orogen by geochronological and thermochronological investigation. ${ }^{40} \mathrm{Ar} /{ }^{39} \mathrm{Ar}$ thermochronological approaches based on contrasted diffusion of argon in K-bearing minerals with variable retentivity has been increasingly applied to resolve complex cooling histories (McDougall and Harrison, 1999, and references therein). Variable cooling and exhumation rates have been reported for several orogenic belts, e.g., the Himalayan in Southeastern Tibet (Quidelleur et al., 1997; Harrison et al., 2000), the Pyrenean part of the Hercynian chain (Maurel et al., 2004), the Mesoproterozoic Albany-Fraser Orogen in Western Australia (Scibiorski et al., 2015), or the Eburnean Orogen in the West African Craton (Sagna et al., 2021). In most cases, these studies showed fast cooling and exhumation rates associated with tectonic compression, and much lower cooling rates during late denudation by erosion processes. Such ${ }^{40} \mathrm{Ar} /{ }^{39} \mathrm{Ar}$ thermochronological approaches therefore provide important insights into the thermal 
evolution of the continental crust. Furthermore, they may give valuable information on how, where and when ore deposits may form at depth during the typical development of an orogen, which can also have significant economic impact.

Here we present a $\mathrm{K}$-Ar and ${ }^{40} \mathrm{Ar} /{ }^{39} \mathrm{Ar}$ geochronological and thermochronological study on granitic batholiths from the two main structural zones of the Variscan Orogen in western Iberia, the Ossa-Morena and Central Iberian zones, and one sample from a parautochthonous complex in the Galicia-Trás-os-Montes Zone (Fig. 1). The combined analysis of minerals with contrasted Ar retentivity and closing temperatures, coupled with available U-Pb data, allows us to reconstruct the thermal and vertical displacement history of the roots of the Variscan Orogen in Iberia during its late stages.

\section{Geological background}

The Variscan belt was produced by the convergence and collision between Laurussia and Gondwana, after the closure of the Rheic Ocean. The belt is characterized by several geotectonic zones with specific paleogeographic, tectonic, metamorphic and magmatic characteristics (Matte, 1991; Quesada, 1991; Franke, 2000; Simancas et al., 2005; Rosas et al., 2008; Murphy et al., 2016). Subduction with exhumation and retrogression to amphibolite facies of earlier granulite and eclogite rocks took place at ca. 390 Ma (Dallmeyer et al., 1991). It was followed by continental collision at around $370 \mathrm{Ma}$ (Moita et al., 2005a, b). Three main phases of contractional deformation ( $\mathrm{C} 1$ to $\mathrm{C} 3$; Fig. 2) and two extensional events (E1 and E2; Fig. 2) under given metamorphic conditions (M1 to M3) and igneous processes (I1 to I3) are considered responsible for the structures presently observed (e.g. Martínez Catalán et al., 2014). 
correspond to the most internal parts of the Variscan Belt in the Iberian Peninsula (Julivert et

110 al. 1974; Farias et al. 1987). Metamorphic conditions recorded in these zones can be

111 summarized as follows (Ribeiro et al, 2019): the allochthonous massifs of the Galicia-Trás-

112 os-Montes Zone show MP-HT and HP-HT in the Upper Allochthon, HP-LT in the Middle

113 Allochthon, and MP-MT in the Lower Allochthon; the Ossa-Morena Zone records LP-HT in

114 the Parautochthonous, MP-LT and HP-MT in the Allochthon, and HP-HT close to the contact

115 with the Central Iberian Zone, whereas LP-LT metamorphic conditions have been recorded in

116 the South Portuguese Zone. Finally, domal areas of the Central Iberian Zone show P-T paths

117 from LP-LT to MP-HT. These metamorphic conditions reflect the three main stages of the

118 Variscan cycle: (1) LP-HT associated with the Cambrian-Early Ordovician rift stage; (2) HP-

119 LT associated with subduction; and (3) syn-to-post-collisional, MP and LP/HT in the

120 hinterland and foreland fold-and-thrust belts. Thrusting of high-grade rocks to lower crustal

121 levels produced retrogression to lower amphibolite and greenschist facies. Syn- and post-

122 orogenic collapses were also responsible for retrogression to greenschist facies, especially in

123 the core of the Variscan chain where post-orogenic isostatic rebound and denudation brought

124 deep-seated rocks to the surface.

The Central Iberian, the Galicia-Trás-os-Montes and the Ossa-Morena zones are

126 delimited by major shear zones that have played an essential role in the late development and

127 exhumation of the Variscan Orogen in Iberia. The Coimbra-Badajoz-Cordova shear zone is a

WNW-ESE mega-shear, which represents an aborted continental rift during Lower Paleozoic times that evolved to a sinistral Variscan flower structure in the upper Paleozoic (Ribeiro et al., 1990). It represents the limit between the Central Iberian and Ossa-Morena zones. The 131 pressures and temperatures reached during the earlier Cadomian Orogeny (Upper Proterozoic) 132 and during the M1 and M2 Variscan phases (Upper Paleozoic) indicate a poly metamorphic 133 evolution of the Badajoz-Cordoba shear zone (Ábalos et al., 1991). The Juzbado-Penalva do 
134 Castelo Shear Zone is an ENE-WSW sinistral shear zone (Iglesias and Ribeiro, 1981), which

135 brought into contact the Figueira de Castelo Rodrigo-Lumbrales Anatectic Complex (S-type 136 granites and migmatites) with low-grade metamorphic units from the autochthonous of the

137 Central Iberian Zone (Ferreira et al. 2019). Exhumation rates associated with non-purely 138 horizontal strike-slip along the Juzbado-Penalva do Castelo Shear Zone has been recently 139 estimated at ca. $800 \mathrm{~m} / \mathrm{Ma}$ between ca. 315 and $305 \mathrm{Ma}$ (Ferreira et al., 2019). felsic magmas were generated and emplaced into Neoproterozoic to Palaeozoic sequences of meta-sedimentary and meta-igneous rocks of variable metamorphic grades. Plutonic bodies, based on their geological, petrographic and geochemical characteristics, have been divided into two main groups (e.g., Capdevila et al., 1973; Bea et al., 1999; Ferreira et al. 1987; Dias et al., 2002). A first group consists of two-mica peraluminous granites, considered S-type and resulting from the crystallization of wet peraluminous magmas, whose origin at a mid-crustal 147 level is related to orogenic metamorphism. These granites formed in the core of thermal 148 domes nearly coincident with late Variscan large-scale antiforms. The second group consists of biotite-rich granites (I-Type), which represent the products of complex lower-crustal melting with possible mixture with mantle-derived magmas (e.g. Dias et al., 1998; Orejana et al., 2009; Villaseca et al., 2011). The biotite-rich granites are distributed parallel to ductile 152 shear zones trending NNW-SSE, ENE-WSW and NNE-SSW (Ferreira et al., 1987; Dias et al., 153 2002; Valle Aguado et al. 2005).

From zircon and monazite $\mathrm{U}-\mathrm{Pb}$ ages obtained on samples from the Central Iberian and Galicia-Trás-os-Montes zones, the two types of granites have been further divided into several age subgroups. The S-type granites have been divided into three sub-groups: 331-321 Ma, 317-315 Ma and 311-310 Ma. The biotite-rich I-Type granites have been divided into four subgroups: late-E1 (320-315 Ma), syn-C3 (310-305 Ma), and late-C3 and E2 (305-280 
Ma) (Dias et al., 1998; Dias et al., 2002; Valle-Aguado, 2005; Neiva et al., 2012; Pereira et al., 2018 and references therein). Considering I-Type magmatism from the Ossa-Morena Zone represented by synkinematic gabbros, granodiorites and tonalites, and older granodiorites from Galicia, we can distinguish an older, generalized episode of I-Type magmatism (early I1) from ca 370 to $335 \mathrm{Ma}$ (Moita et al., 2005a,b; Jesus et al., 2007; Pin et al., 2008; Pereira et al., 2015; Gutiérrez-Alonso et al., 2018).

Several metallogenetic events associated with granites have been recognized (e.g., Neiva, 2002; Mateus and Noronha, 2010). Mostly Sn pegmatites and quartz veins with cassiterite precipitated during the early stage. They are related to S-type granites and are generally associated with quartz, muscovite and arsenopyrite. W (Sn) in quartz-vein deposits are related to late-C3 biotite granites, and $\mathrm{W}(\mathrm{Mo})$ quartz veins and stockworks are related to the E2 youngest biotite granites. Fluid inclusion and isotope data show that the biotite-rich Variscan granites (310 to $280 \mathrm{Ma}$ ) may also play a different role in the $\mathrm{W}$ ore forming processes, because no typical magmatic signature is found in mineralizing fluids, except in the earliest stages responsible for the greisen formation. The heat flow regime supports a late extensive hydrothermal activity throughout the entire crust, involving distinct fluid sources in successively lower P-T conditions along a continuum that provided long-lived hydrothermal systems (Mateus and Noronha, 2010; Noronha, 2017, and references therein).

The age of $\mathrm{W}$ and $\mathrm{Sn}$ mineralizations is still a matter of debate, due to very scarce geochronological data, which might be biased by late hydrothermal events and alteration processes. In the northeast Galicia-Trás-os-Montes Zone and in the northern part of the Central Iberian zone, deformed Sn-pegmatites associated with cassiterite deposits in the exocontact of a syn-C3 granite were dated at $307 \pm 3$ Ma by Rb-Sr (Priem and den Tex, 1984), whereas recent $\mathrm{U}-\mathrm{Pb}$ ages on cassiterite range from $331 \pm 5.6$ to $310 \pm 6 \mathrm{Ma}$ (Zhang et al., 2019). U-Pb ages on minerals of the columbite-tantalite group from pegmatites in the exo- 
contact of a late-C3 biotite-muscovite granite yielded ages of $301 \pm 4$ and $316 \pm 9 \mathrm{Ma}$ (Lima et al., 2013). ${ }^{40} \mathrm{Ar} /{ }^{39} \mathrm{Ar}$ ages on muscovite from similar non-deformed veins of pegmatite and quartz including lithium minerals and fine cassiterite near the Portugal-Spain border recorded two age groups around 305 and 295 Ma (Vieira et al., 2011). Further to the northwest, the hydrothermal systems of $\mathrm{W}(\mathrm{Mo})$ at Borralha record post-magmatic cooling associated with the youngest E2 biotite granites in the Galicia-Trás-os-Montes Zone. An ${ }^{40} \mathrm{Ar} /{ }^{39} \mathrm{Ar}$ age of $286.8 \pm 1.2 \mathrm{Ma}$ on muscovite probably reflects secondary formation from magmatic biotite or feldspar alteration, while an age of $280.9 \pm 1.2 \mathrm{Ma}$ in sericite may date the age of greisen alteration $\left(\mathrm{T} \sim 300^{\circ} \mathrm{C}\right)$. Ages of $281.3 \pm 1.2$ and $277.3 \pm 1.3$ Ma were obtained on muscovite (selvage) crystallized adjacent to molybdenite rich veins (Bobos et al., 2019), in very good agreement with the previous zircon $\mathrm{U}-\mathrm{Pb}$ age of $280 \pm 5 \mathrm{Ma}$ for the Gerês E2 biotite granite. A younger K-Ar age of $273 \pm 1.1 \mathrm{Ma}$ was obtained on feldspar resulting from hydrothermal alteration of the Gerês granite (Jaques et al., 2016).

At Panasqueira (southern part of the Central Iberian Zone) the largest W (Sn) deposit in the Iberian Peninsula is spatially associated with a greisen cupola. ${ }^{40} \mathrm{Ar} /{ }^{39} \mathrm{Ar}$ ages on muscovite from quartz veins and greisen constrain fluid circulation between $296.3 \pm 0.8$ and $291.6 \pm 0.8 \mathrm{Ma}$ (Snee et al., 1988). The earliest hydrothermal event (tourmalinization) was recently dated at $305.2 \pm 5.7 \mathrm{Ma}$ by $\mathrm{U}-\mathrm{Pb}$ on rutile (Carocci et al., 2019) and at $303.0 \pm 3.3$ and $301 \pm 4.2 \mathrm{Ma}$ by U-Pb on cassiterite (Zhang et al., 2019). In addition, a U-Pb age of 296.3 \pm 4.2 Ma was obtained on apatite from the Panasqueira greisen, which is similar to a U-Pb age of $294.5 \pm 5.3 \mathrm{Ma}$ obtained on apatite from the mineralized veins (Launay, 2018). All these data are seemingly contradictory. This may be the result of the complex and long history typical of a large deposit that implies successive reopening of mineralized veins. 


\section{Methods}

209

211

212

213

214

215

\subsection{Sampling strategy and description}

Forty-five granitic outcrops in Central and Northern Portugal were studied and sampled, in order to measure the visible strain and assess the timing of pluton emplacement, the age of the main deformation episodes, and the exhumation of the roots of the Variscan orogen in western Iberia. Deformation markers (faults, foliation, mineral lineation) were measured as trends, providing a qualitative estimation of strain and its dominant orientation, as reported in Table 1. Sampling initiated in the south near the city of Évora and progressed northwards along a SSE-NNW transect across the Ossa-Morena and Central Iberian zones, ending in the Galicia-Trás-os-Montes Zone. Only twelve out of the forty-five samples collected were dated. In each zone, representative samples were selected for argon geochronological and thermochronological studies based on their freshness and location in the orogen, as well as type and degree of strain (Table 1). The analysed samples are reported on a synthetic map showing the main Variscan and pre-Variscan chrono-stratigraphic units (Fig. 1). For each sample, a detailed description of the geological unit such as given in the Geological Map of Portugal scaled at 1/500 000 (LNEG, 1992) is also provided (Table 1, Supplement 1).

The five samples collected in the Ossa-Morena Zone (Fig.1) include pre-, syn- and post-orogenic granitoids $(s l)$, ranging from highly deformed to un-deformed. Near Évora, we sampled a pervasively foliated, biotite-rich granitoid (sample 107D) referred to as "Proterozoic rocks partially migmatized during the Variscan Orogeny" (Table 1). Slightly further East, near Vendinha, we collected a less-deformed granite (sample 107G), described as a "syn-orogenic tonalite" (Fig. 1, Table 1). On the geological map (LNEG, 1992), both outcrops are part of an elliptical large body roughly elongated NW-SE, which may have (re-) crystallized during a main deformation stage of the Variscan orogeny. Further north, sample 
107J, collected near Pavia village, is from a weakly deformed two-micas porphyroid granite.

233 It is mapped as cutting Variscan tonalites and should therefore be younger; however, the 234 contact is unclear and seems to be made up of small faults. In any case, this granite is also 235 mapped as "orogenic" in the geological map (LNEG, 1992, Table 1). Further north, near 236 Campo Maior, another "orogenic" plutonic body mapped as anorthosite gabbro (though 237 containing biotite) was also collected (sample 107P). Finally, an undeformed porphyroid 238 granite cutting previous units, referred to as late-Variscan in the geological map (LNEG, 239 1992), was collected close to the northern boundary of the Ossa-Morena Zone near the 240 Monforte village (sample 107K).

The six studied Central Iberian Zone granites also range from deformed to undeformed. Sample 107T is from an undeformed granite collected near the Alpalhão village, 243 close to the boundary between the Central Iberian and Ossa-Morena zones (Fig. 1). Sample 244 107X is from an isolated biotite-bearing quartz-diorite batholith near the Fundão town, 245 considered either as a "syn-tectonic" granite (LNEG, 1992), or a pre-Variscan Ordovician 246 granite and tonalite from zircon $\mathrm{U}-\mathrm{Pb}$ ages around $478 \pm 2 \mathrm{Ma}$ reported more recently by 247 Antunes et al. (2012). A few tens of kilometres further to the NE, near the border with Spain, 248 we sampled a biotite granite with minor muscovite (sample 107AC), which is cut by E-W to 249 NE-SW normal faults (Table 1), thus pointing to a late tectonic (regional?) event with a N-S 250 to NW-SE extensional component. We note that the NE direction is also marked by numerous 251 felsic dykes in the area (Table 1). A few $\mathrm{km}$ to the north, deformed granites and gneisses are 252 also elongated along the ENE-WSW direction, but they are mapped as emplaced during early 253 deformation events. We sampled a lenticular gneiss with minor muscovite (sample 107AH2), 254 and a so-called "syn-tectonic granite" (sample 107AJ). The latter is affected by two distinct 255 vertical foliation planes (S-C mylonite), one oriented N135 (S-type) and the other N090 to 256 N100 (C-type), with a 15-N100 stretching lineation and shear criteria indicating left-lateral 
257 kinematics (Table 1). In contrast, many structures with a dominant NW-SE orientation occur 258 further west. These include a NW-SE elongated deformed granite (sample 107AN) emplaced 259 during E1 stage, which we collected at Lamego town. The granite is cut by a major NW-SE 260 fault zone that can be followed on the geological map for several tens of kilometres (Fig. 1).

263 Central Iberian Zone stricto sensu, it is a granite intruded into the Galicia-Trás-os-Montes 264 Zone.

\section{2. $K$-Ar and ${ }^{40} A r{ }^{39} A r$ dating}

Careful examination of thin sections (Supplementary Fig. 1) was conducted to constrain the main petrographic characteristics of the samples and ensure that they did not undergo significant weathering, which is critical for subsequent reliable argon dating. All the samples are granitoids s.l. (granodiorites, fine-grained granites, porphyroid granites, aplites

271 dykes, orthogneisses), with structures and textures ranging from equant, isotropic and 272 undeformed to the naked eye, to strongly foliated (S-tectonite) or conspicuously lineated (L273 tectonite). The mineralogy is dominated by K-feldspar \pm quartz \pm mica (biotite, or muscovite, 274 or both), and includes some accessory minerals such as apatite, titanite, oxides and 275 occasionally tourmaline.

After crushing and sieving to a grain size in the interval $250-500 \mu \mathrm{m}$, the various $\mathrm{K}$ -

277 bearing mineral phases were extracted by means of magnetic separator and heavy liquids.

278 Whenever possible, either two or three distinct mineral phases were selected for a given sample. For two-mica granites (107J, 107T and 107AC), especially, muscovite, biotite and K- 
feldspar were extracted. Such separation is essential to check for internal consistency within

281 the sample and evaluate whether the ages measured may reflect crystallization age or cooling, as these various phases have different Ar retentivity with respect to temperature. As such, 283 they can be used to carry out a thermo-chronological study aimed at constraining the path of 284 the samples through the different isotherms, and thus discuss the thermal history in terms of 285 exhumation and/or potential partial resetting during thermal events.

The K-Ar and ${ }^{40} \mathrm{Ar} /{ }^{39} \mathrm{Ar}$ analyses were carried out at the GEOPS Laboratory in Orsay 287 (France). Details on the K-Ar analytical procedure and its applicability can be found 288 elsewhere (Gillot et al., 2006). For each mineral phase, K was measured at least twice by 289 flame absorption photometry, and compared with standards MDO-G (Gillot et al., 1992) and BCR2 (Rackzek et al., 2001). The K-value is the arithmetic average of independent measurements and is considered final when the relative standard deviation $(1 \sigma)$ is lower than $1 \%$. The ${ }^{40} \mathrm{Ar} /{ }^{36} \mathrm{Ar}$ isotopic composition was measured on a $180^{\circ}$ sector multi-collector massspectrometer similar to the one described in Cassignol and Gillot (1982) and Gillot and Cornette (1986). At least two independent Ar measurements were completed on both biotite and muscovite and the final $\mathrm{K}-\mathrm{Ar}$ age is calculated as the weighted-mean of individual determinations consistent at the $1 \sigma$ level. One Ar determination was conducted in K-feldspar of the samples for preliminary purposes, as K-Ar ages on such phases generally provide inconclusive information regarding granite crystallization age at depth due to their poor $\mathrm{Ar}$ retentivity at high temperature (e.g. Sagna et al., 2017). However, K-feldspar can be used to 300 achieve a thermochronological analysis through step-heating ${ }^{40} \mathrm{Ar} /{ }^{39} \mathrm{Ar}$ (see next section, and 301 Lovera et al., 1997; Sagna et al., 2021). The ${ }^{40} \mathrm{Ar} /{ }^{39} \mathrm{Ar}$ analyses were performed using the multi-collector mass-spectrometer 303 and procedure described by Coulié et al. (2004). Aliquots of the samples (30 to $80 \mathrm{mg}$ ) were 304 first irradiated along with fluence monitors during $60 \mathrm{~h}$ in the Corvallis Triga reactor 
(Radiation Center, Oregon state University, USA), using the CLICIT facility. Gas extraction

306 of the samples was completed by step heating with a high frequency furnace. A Nd-YAG 307 laser $(1064 \mathrm{~nm})$ was used to fuse $20 \mathrm{mg}$ aliquots of the Heidelberg biotite international 308 standard HD-B1 (Fuhrmann et al., 1987), in order to determine the J factors based on the age 309 of 24.18 Ma for HD-B1 (Schwartz and Trieloff, 2007). The mass discrimination was 310 corrected using a linear law applied to analyses of air aliquots measured with the same ${ }^{40} \mathrm{Ar}$ 311 signal intensity as that measured for a typical step. The $\mathrm{K}$ isotopic ratio and ${ }^{40} \mathrm{~K}$ decay constants of Steiger and Jäger (1977) were used. It has been demonstrated that ${ }^{40} \mathrm{Ar} /{ }^{39} \mathrm{Ar}$ ages with $0.1 \%$ of analytical relative precision can be reached with our instrument (e.g. Ricci et al., 2013). However, as ${ }^{40} \mathrm{Ar} /{ }^{39} \mathrm{Ar}$ dating is relative to the flux monitor age, this represents the main limiting factor for the accuracy of this technique (Kuiper et al., 2008). It should be noted that differences of about $1 \%$ exist for the admitted ages of commonly used fluence monitors such as Fish Canyon Tuff Sanidine and HDB-1. These differences can be explained by inter-

318 laboratory biases, or by the presence of previously undetected ${ }^{39} \mathrm{Ar}$ recoil (Phillips et al., 2017). Therefore, the ${ }^{40} \mathrm{Ar} /{ }^{39} \mathrm{Ar}$ total age uncertainties from the present study include a systematic error of $1 \%$ for the J-Factor determination.

\section{3. ${ }^{40} \mathrm{Ar}{ }^{\beta 9} \mathrm{Ar}$ thermochronology}

The multi-diffusion domain approach (MDD) was used here to reconstruct the thermal history recorded in K-feldspars of key samples (107J, T, X, AC and AS). The MDD approach relies on the hypothesis that diffusion of Ar occurs similarly in nature as in the laboratory and that diffusion of Ar in K-feldspar can be modelled by a discrete distribution of non-interacting

327 domains (Lovera et al., 1989; Lovera, 1992). Using the laboratory ${ }^{40} \mathrm{Ar} /{ }^{39} \mathrm{Ar}$ step-heating measurements, diffusion parameters (i.e. activation energy and frequency factor) can be 
recovered from the Arrhenius diagram built using the degassing systematics of reactor-

330 produced ${ }^{39} \mathrm{Ar}_{\mathrm{K}}$ (Lovera et al., 1989). In the case of our samples, the first degassing steps did 331 not allow a precise determination of the activation energy (see Supplementary Figures 1 and 332 2) and hence the value of $46 \pm 6 \mathrm{kcal}_{\mathrm{mol}}{ }^{-1}$ typically used for K-feldspar was imposed 333 (Lovera et al., 1997). Monotonic cooling histories can be computed using inverse modelling, 334 hence without an a-priori thermal history. On the other hand, a forward modelling approach 335 with an input thermal history is necessary when post emplacement re-heating is considered. In 336 our case, forward modelling was achieved using constraints obtained from biotite and 337 muscovite (closure temperatures of $300{ }^{\circ} \mathrm{C}$ and $350{ }^{\circ} \mathrm{C}$, respectively; McDougall and Harrison, 338 1999), and available U-Pb ages on zircons $\left(\mathrm{T}>650{ }^{\circ} \mathrm{C}\right)$. The cooling history that best 339 reproduces the degassing age spectra is shown for each sample (Supplementary Figure 3). 340 Finally, we tested the potential effects of a thermal event, by imposing moderate re-heating 341 (RH) below a temperature of $300{ }^{\circ} \mathrm{C}$ (closure temperature of biotite) at various epochs (200 342 Ma, 240 Ma, and 260 Ma, Supplementary Fig. 4) for our best-characterized sample (107AC).

\section{Results}

\subsection{K-Ar and ${ }^{40} \mathrm{Ar} /{ }^{39} \mathrm{Ar}$ dating}

The new K-Ar ages (Table 2) range from $264 \pm 4$ to $335 \pm 3$ Ma. For samples with 3

347 mineral phases analysed ( $\mathrm{J}, \mathrm{T}, \mathrm{AC}), \mathrm{K}-\mathrm{Ar}$ ages on biotite and muscovite are mutually 348 indistinguishable within the range of uncertainties. Preliminary ages on K-feldspar for these 349 samples are, however, systematically younger by more than $20 \mathrm{Ma}$, and up to $30 \mathrm{Ma}$ (Table 2). 350 Such discrepancy is significant, as it represents a relative offset of ca 10\%. Sample 107X, for 351 which only two phases were available, shows a similar behaviour, with K-Ar ages of $288 \pm 4$ and $264 \pm 4$ Ma obtained on biotite and K-feldspar, respectively. 
${ }^{40} \mathrm{Ar} /{ }^{39} \mathrm{Ar}$ age spectra obtained during incremental step-heating on biotite and

354 muscovite produced relatively well-defined plateaus (Fig. 3), with more than $50 \%$ of ${ }^{39} \mathrm{Ar}$ gas released and a minimum of three steps, all steps included in the plateau being consistent at the 20 level (e.g., Fleck et al., 1977; McDougall and Harrison, 1999). We note, however, that biotites from samples $107 \mathrm{~J}$ and $107 \mathrm{X}$ do not meet these criteria, due to the presence of steps with older apparent ages at relatively high temperatures, which may reflect the contribution of inclusions of incompletely reset accessory minerals, e.g. small oxide grains. Such minerals, along with apatite, frequently occur in the samples (as observed in thin section). However, such effect appears limited, as revealed by the overall flat shape of the spectra. Similar outlier steps also occur for biotites from samples 107T, 107AC and 107AN, but in these cases they 363 do not preclude the definition of a plateau. The effect is negligible as plateau ages and 364 integrated ages for these samples are fully consistent. In other words, removing the outliers would define a more robust plateau, i.e. calculated from a higher ${ }^{39} \mathrm{Ar}$ content, but with negligible effect on the total gas age. The spectra on muscovite are even flatter and provide 367 similar plateau and integrated ages (Fig. 3). They also yield comparable results with the ${ }^{40} \mathrm{Ar} /{ }^{39} \mathrm{Ar}$ obtained on biotite of the same samples and are fully compatible with the K-Ar ages (Fig. 4).

In contrast, the spectra obtained during incremental heating of K-feldspar (Fig. 5)

371 from the various samples show a clear stairway shape, typical of either a long gradual cooling history or thermal disturbance (re-heating; McDougall and Harrison, 1999). Inverse modelling (monotonic cooling) and forward modelling give similar results for the feldspars of samples 107AC and 107AS (Fig. 6 and Supplementary Figs. 2 and 3). This 
confirms the relevance of the value of $46 \mathrm{Kcal} / \mathrm{mol}$ used for activation energy (Lovera et al., 1997) for all our samples. The cooling histories (300-250 Ma) imposed for forward MDD modelling that best fit ${ }^{40} \mathrm{Ar} /{ }^{39} \mathrm{Ar}$ age spectra for feldspars from our samples $107 \mathrm{~J}, 107 \mathrm{X}$, 107AC, and 107AS (see Supplementary Figure 4) are shown on Figure 7. While sample AS records a relatively early and fast temperature drop after $300 \mathrm{Ma}$, samples $\mathrm{J}, \mathrm{X}$ and AC show a much longer cooling history. The latter two samples especially, which belong to the Central Iberian Zone, record temperatures exceeding $200{ }^{\circ} \mathrm{C}$ until ca. $250 \mathrm{Ma}$.

Results of our test regarding a possible re-heating event are shown on Supplementary Figures 5. The first two tests (re-heating at $200 \mathrm{Ma}$ and $240 \mathrm{Ma}$ ) fail to reproduce any of the apparent ages of the degassing spectra. Conversely, a re-heating of about $275^{\circ} \mathrm{C}$ at $260 \mathrm{Ma}$ (blue line in Supplementary Figure 5C) fits most of the spectra relatively well, but is not substantially better than the simplest hypothesis of monotonic cooling since $300 \mathrm{Ma}$.

\section{Discussion}

Overall, the new ${ }^{40} \mathrm{Ar} /{ }^{39} \mathrm{Ar}$ ages (Table 3 and Figs. 5-6) confirm the validity of the new $\mathrm{K}$-Ar ages and show that none of our samples have undergone significant thermal disturbance above the closure temperature of biotite (i.e. ca. $300{ }^{\circ} \mathrm{C}$ ). By extrapolation, this also supports the validity of the K-Ar ages on biotite for samples not analysed with ${ }^{40} \mathrm{Ar} /{ }^{39} \mathrm{Ar}$, especially 107D and 107G (see also comparison with available U-Pb ages in Supplement 1). In contrast, the abnormally young K-Ar ages systematically obtained on K-feldspars from our samples, and the stairway shape of the degassing ${ }^{40} \mathrm{Ar} /{ }^{39} \mathrm{Ar}$ spectra (Fig. 5), both reflect incomplete $\mathrm{Ar}$ retention. Our MDD modelling test for re-heating does not support significant re-opening of the Ar system due to re-heating (Supplementary Fig. 5), ruling out significant contribution from large, generalized thermal events, such as the plume-related emplacement of the Central 
Atlantic Magmatic Province (CAMP) ca. 200 Ma ago (e.g., Marzoli et al., 1999; Nomade et al., 2007). This is consistent with recent apatite fission-track data obtained on two of our samples (107T and AC), which show no detectable temperature increase beyond $60-110{ }^{\circ} \mathrm{C}$ during the last $250 \mathrm{Ma}$ (Barbarand et al., 2021). Therefore, the thermal histories recorded by the various mineral phases of our various samples (muscovite, biotite, and K-feldspar) most likely reflect monotonic cooling at various rates in relation to granite emplacement and exhumation.

\subsection{Syn- and post-deformation episodes of granite production: where and when?}

Comparison of the new K-Ar and ${ }^{40} \mathrm{Ar} /{ }^{39} \mathrm{Ar}$ ages on biotite and muscovite with available U-Pb data on zircon inferred to represent true crystallization age of the granites is given for each sample in Supplement 1 and shown on Fig. 8. In summary, the new K-Ar and

${ }^{40} \mathrm{Ar} /{ }^{39} \mathrm{Ar}$ ages on micas are either similar to or slightly lower than existing $\mathrm{U}-\mathrm{Pb}$ ages on zircon. In the former case, the new ages are consistent with U-Pb crystallization ages, despite the great difference in closure temperature: up to ca. $900{ }^{\circ} \mathrm{C}$ for U-Pb in zircon (Lee et al., 1997), compared to ca. 350 or ca. $300{ }^{\circ} \mathrm{C}$ for $\mathrm{Ar}$ in muscovite or biotite, respectively

417 (McDougall and Harrison, 1999). We thus infer rapid cooling. Rapid cooling can take place in 418 two situations: granite emplacement at relatively shallow crustal level $\left(\mathrm{T}<300{ }^{\circ} \mathrm{C}\right)$, or granite 419 emplacement during very fast uplift. A U-Pb age significantly older than the Ar age indicates 420 a different thermal history, which can be explained by crystallization at greater depth (T > 421 closure temperature of muscovite), followed by relatively slow cooling. Plotting the new mica K-Ar and ${ }^{40} \mathrm{Ar} /{ }^{39} \mathrm{Ar}$ ages on a structural map of Portugal (Fig. 9) 423 allows several main patterns to be distinguished, which are summarized as follows: 
425 from $335 \pm 3 \mathrm{Ma}$ (sample 107D) to $290 \pm 4 \mathrm{Ma}(107 \mathrm{AJ})$. The youngest age (sample 107X, ca. $426285 \mathrm{Ma}$ ), however, departs from the general trend.- Two main age groups occur according to 427 the two main tectonic zones. Samples in the Central Iberian Zone are constrained between 428305 and $285 \mathrm{Ma}$, whereas samples from the Ossa-Morena and Galicia-Trás-os-Montes zones 429 are dated in the range 335-305 Ma. Regarding the Galicia- Trás-os-Montes Zone, however, a 430 sampling bias is possible, as only one sample (107AS) has been analysed here, whereas U-Pb ages as young as $280 \pm 5$ Ma have been reported for E2 biotite granites in this area (Mendes and Dias, 2004). Older granites in Galicia and northern Portugal have been dated around 347310 Ma (Martínez Catalán et al., 2014; Gutiérrez-Alonso et al., 2018), which is comparable to

434 the age of synkinematic gabbros, granodiorites, and tonalites in the Ossa-Morena Zone. 435 However, the oldest granites from Galicia and northern Portugal are associated with Variscan 436 shear zones, whereas deformed plutonic bodies in the southern Ossa-Morena Zone show 437 tholeiitic to calc-alkaline affinities associated with subduction processes (e.g., Pereira et al., 2015).

- Within each of the zones investigated here, the oldest $\mathrm{K}-\mathrm{Ar}$ and ${ }^{40} \mathrm{Ar} /{ }^{39} \mathrm{Ar}$ ages are obtained on deformed granites. In the Ossa-Morena Zone, the rocks with greater deformation occur along the NW direction and are dated in the range 335-310 Ma, whereas undeformed granites 442 cross-cutting previous units (samples $107 \mathrm{~K}$ and $107 \mathrm{P}$ ) yield $\mathrm{K}-\mathrm{Ar}$ and ${ }^{40} \mathrm{Ar} /{ }^{39} \mathrm{Ar}$ ages closer to $443305 \mathrm{Ma}$. In the Central Iberian Zone (and Galicia-Trás-os-Montes Zone, sample 107AS) ages 444 around 305-300 Ma are obtained on samples along major tectonic structures with a similar 445 NW-SE trend. In addition, a group of rocks with significant superimposed late deformation 446 along the NE-SW to E-W direction in the Central Iberian Zone (107X, 107AC, 107AH2) is 447 here dated around 295-285 Ma.

448 - Strongly deformed samples from the Ossa-Morena Zone (107D and 107G) show similar U$449 \mathrm{~Pb}$ and $\mathrm{K}-\mathrm{Ar}$ ages, supporting very rapid cooling after (syn-tectonic) crystallization. For these 
samples, steep pervasive foliation and mineral lineation striking N160 and N170 (samples

451 107D and 107G, respectively) suggest an important event of ductile stretching ca. 335-325

452 Ma ago.

453

454

455

456

457

- Undeformed samples from both the Ossa-Morena and the Galicia-Trás-os-Montes zones also show very similar U-Pb, K-Ar and ${ }^{40} \mathrm{Ar} /{ }^{39} \mathrm{Ar}$ ages, but the lack of obvious syn-kinematic (ductile) crystallization for these samples supports granite emplacement and rapid cooling at a shallow level around 305 Ma.

- In contrast, an offset from a few Ma up to $30 \mathrm{Ma}$ is observed between U-Pb and the new $\mathrm{K}$ Ar and ${ }^{40} \mathrm{Ar} /{ }^{39} \mathrm{Ar}$ ages for our deformed samples from the Central Iberian Zone and also for the sample 107J from the Ossa-Morena Zone. This suggests that the crystallization of these granites constrained by $\mathrm{U}-\mathrm{Pb}$ ages occurred relatively deep. Then, their subsequent cooling occurred over millions of years at a slower rate, as constrained by the ${ }^{40} \mathrm{Ar} /{ }^{39} \mathrm{Ar}$ ages. This may be due to the position of the sampled granites closer to the axis of the chain, where important deformation and thickening of the crust occurred, leaving the corresponding rocks at depth for a relatively long period of time before their exhumation by either tectonic processes or late erosion and isostasy.

\subsection{Exhumation rates and processes}

The long-lasting thermal history recorded by some of our samples (several Ma difference between $\mathrm{U}-\mathrm{Pb}$ and $\mathrm{Ar}$ ages) is unlikely to result solely from in-situ cooling at a fixed vertical position after granite emplacement/crystallization. It has been shown that a batch of liquid granitic magma of a few cubic kilometres emplaced at depths around 6-8 km (e.g., Vigneresse, 1999) cools down to around $300{ }^{\circ} \mathrm{C}$ on timescales of only a few tens of thousands of years (e.g., Nabelek et al., 2012). Such period is far shorter than the uncertainty 
474 of both $\mathrm{U}-\mathrm{Pb}, \mathrm{K}-\mathrm{Ar}$ and ${ }^{40} \mathrm{Ar} /{ }^{39} \mathrm{Ar}$ ages. On the other hand, a long-lasting thermal evolution

475 exceeding a few Ma more realistically records the successive positions of the granitic bodies

476 at various depths. Therefore, monotonic cooling rates can be reasonably interpreted in terms

477 of exhumation rates. For consistency with earlier works on batholiths from Portugal, we will

478 use an average geothermal gradient of $42{ }^{\circ} \mathrm{C} / \mathrm{km}$ (Pereira et al., 2017) throughout the period

479 of interest. From the reconstructed thermal history of our 4 samples (107J, X, AC and AS, Fig.

480 7), we can draw a synthetic cartoon showing the position of the granites along a main N-S

481 cross-section passing through the Ossa-Morena, Central Iberian and Galicia-Trás-os-Montes

482 zones at decreasing ages (Fig. 10):

483

- At 300 Ma, our samples from the Ossa-Morena (107J) and Galicia-Trás-os-Montes (107AS) zones were already located at shallow depths $\left(\mathrm{T}<300{ }^{\circ} \mathrm{C}, \mathrm{d} \approx 7 \mathrm{~km}\right)$, whereas samples from the Central Iberian Zone (107X and 107AC) had just crystallized at a deeper structural level $(\mathrm{d}>15 \mathrm{~km})$.

- Between 300 and $285 \mathrm{Ma}$, sample 107J experienced relatively modest cooling $\left(2{ }^{\circ} \mathrm{C} / \mathrm{Ma}\right)$ and slight uplift (ca. $1 \mathrm{~km}$ ), supporting a rather stable character of the central part of the OssaMorena Zone, which was structured and tectonically exhumed by intra-orogenic collapse well 490 before (no evidence for significant deformation after $325 \mathrm{Ma}$ ). Over the same period, 491 feldspars of our three other samples (107X, AC and AS) show relatively rapid cooling (12$\left.25{ }^{\circ} \mathrm{C} / \mathrm{Ma}\right)$, corresponding to relatively fast vertical exhumation $(300-600 \mathrm{~m} / \mathrm{Ma})$, which 493 supports a significant influence of tectonics. In the Central Iberian Zone, rates of tectonic 494 exhumation have been recently estimated from $\mathrm{U}-\mathrm{Pb}$ ages obtained on zircon and apatite in 495 deformed granites sampled just to the North of an ENE-WSW trending main sinistral shear zone (Juzbado-Penalva do Castelo Shear Zone), which was active during the late-Variscan C3 contractional stage (Ferreira et al., 2019). From the different closure temperatures of zircon and apatite (ca. $830{ }^{\circ} \mathrm{C}$ and $480{ }^{\circ} \mathrm{C}$, respectively), the authors calculated cooling rates ranging 
from 0 to $35^{\circ} \mathrm{C} / \mathrm{Ma}$, which, for a geothermal gradient of $42^{\circ} \mathrm{C} / \mathrm{km}$ (Pereira et al., 2017), gives an exhumation rate of up to $800 \mathrm{~m} / \mathrm{Ma}$ between ca. 315 and $305 \mathrm{Ma}$. Our deformed gneissic sample 107AH2, also located north of the Juzbado-Penalva do Castelo Shear Zone, yields a K-Ar biotite age of $294 \pm 4 \mathrm{Ma}$, for an estimated U-Pb zircon crystallization age of 313-317 Ma (Table 1 and Supplement 1). Considering closing temperatures of $830{ }^{\circ} \mathrm{C}$ (Ferreira et al., 2019) and $300{ }^{\circ} \mathrm{C}$ for zircon and biotite, respectively, sample $107 \mathrm{AH} 2$ cooled at a rate of 25

${ }^{\circ} \mathrm{C} / \mathrm{Ma}$ over the period 315-295 Ma, corresponding to a vertical exhumation rate of 500-800 $\mathrm{m} / \mathrm{Ma}$. These values are similar to the rates obtained from MDD modelling on feldspars of deformed samples 107X and 107AC, between 300 and 285 Ma. Altogether, these data point to relatively fast cooling and exhumation associated with significant tectonic deformation in 509 the Central Iberian Zone before $285 \mathrm{Ma}$. It should be noted that samples $107 \mathrm{AH} 2$ and $107 \mathrm{AC}$ 510 are located north and south of the Juzbado-Penalva do Castelo Shear Zone, respectively (cf. 511 Fig. 9). This confirms the dominant trans-current movement in the Juzbado-Penalva do 512 Castelo Shear Zone, although with a possible small vertical movement as suggested by 513 Ferreira et al. (2019).

514 - Between 285 and $275 \mathrm{Ma}$, samples 107J and 107X experienced modest cooling and 515 exhumation (5 to $8{ }^{\circ} \mathrm{C} / \mathrm{Ma}$, corresponding to 1 to $2 \mathrm{~km}$ uplift), likely due to denudation and 516 isostatic rebound, whereas samples $107 \mathrm{AC}$ and 107AS do not show any significant sign of 517 cooling/uplift. This period coincides with the emplacement of late-stage (post-orogenic) 518 granites and mineralization events, which marked the end of the Variscan cycle.

519 - Between 275 and $250 \mathrm{Ma}$, most of our samples appear stable and remain close to the surface $520(\mathrm{~d}=3-5 \mathrm{~km})$, except for sample $107 \mathrm{AC}$, which shows slight cooling $\left(4^{\circ} \mathrm{C} / \mathrm{Ma}\right)$ and uplift 521 from ca. $7 \mathrm{~km}$ to $4 \mathrm{~km}$ depth. This time lapse may mark the progressive onset of the alpine 522 cycle, but no obvious imprint is recorded by the feldspars of the four tested samples. 


\subsection{Mineralization processes}

A full characterization of ore forming processes is beyond the scope of the present paper. However, our new data, combined with previous studies (Mateus and Noronha, 2010;

527 Noronha, 2017), provide a general and comprehensive view on the timing of main 528 mineralization events and their genetic link with granite emplacement and exhumation.

530 fluids that migrated in the upper crust at the end of the Variscan orogeny were mixed with

531 surface waters during the decrease in the P-T conditions (Boiron et al., 1996). In mineralized systems, aqueous-carbonic fluids with trapping conditions of $\mathrm{P}$ (50 to $150 \mathrm{MPa}$ ) and $\mathrm{T}$ (300 to $520^{\circ} \mathrm{C}$ ) associated with cassiterite and wolframite are contemporaneous with a thermal peak related to granite emplacement (Noronha et al., 1999; 2013). A continuous input of superficial waters in the system and the decreasing of the P-T conditions yields a dilution of fluids with a rise in density. The fluid-related sulphide deposition $\left(30<\mathrm{P}<100 \mathrm{MPa}\right.$ and $\left.\mathrm{T}<370{ }^{\circ} \mathrm{C}\right)$ are aqueous with low salinity and assumed to result from the mixing of modified fluids with meteoric fluids. Some more saline and colder fluids (brines) have been recognized in quartz veins related to hydrothermal alterations associated with late-Variscan $\mathrm{Pb}$ mineralizations

540 (Marques de Sá et al., 2019). This cycle suggests that fluids are related to granite 541 crystallization relatively deep and that their subsequent cooling occurred at a slow rate, over 542 millions of years, justifying an important role of magmatism in the ore forming processes 543 supplying heat to drive the mineralizing system. The late exhumation can justify the input of 544 surficial fluids into the system. This situation is compatible with the case in which the U-Pb 545 age is significantly older than the Ar age, which can be explained by crystallization at greater 546 depth ( $\mathrm{T}>$ closure temperature of muscovite) followed by relatively slow cooling. The 
547 emplacement of the granitic rocks and the uplift and general decompression of the Variscan 548 units were the main driving forces for fluid migration, as magmatic fluids are relatively scarce 549 in the mineralizing systems. In contrast, undeformed granites with similar $\mathrm{K}-\mathrm{Ar},{ }^{40} \mathrm{Ar} /{ }^{39} \mathrm{Ar}$ mica ages and $\mathrm{U}-\mathrm{Pb}$ 551 zircon ages record rapid cooling. In such case, granite emplacement occurred at relatively 552 shallow crustal levels, and was responsible for contact metamorphism and skarn type breccia 553 pipes deposits (metasomatic deposits).

554

\subsection{Broader implications}

Our data complement existing studies on the Variscan Orogen and others, and provide significant new insights into the complex vertical motions and exhumation mechanisms in evolving orogens.

Several episodes of exhumation, sometimes diachronic, have been previously proposed for the main portions of the Variscan Orogen in central and western Europe:

(1) Early tectonic exhumation associated with subduction of the hyper-extended 562 margins of Gondwana. This episode, which lasted from middle to late Devonian (see recent synthesis in Vanderhaegen et al., 2020), was not investigated in the present study.

(2) Early to mid-Carboniferous exhumation during/after continental collision. This 565 episode is generally attributed to significant thickening of the crust and subsequent collapse of 566 the chain. It has been recorded by metamorphic and syn-orogenic magmatic rocks from 567 several Variscan massifs: in Brittany (Gumiaux et al., 2004), in the French Massif Central 568 (e.g., Gébelin et al., 2009; Chardon et al., 2020), in the western part of the Maures-Tanneron 569 Massif (Morillon et al., 2000; Gerbault et al., 2018), in the Vosges Massif (Boutin et al., 
1995), in the Bohemian Massif and the western Carpathians (e.g., Bues et al., 2002; Franek et al., 2011; Moussalam et al., 2012; Vacek et al., 2019), and in Iberia (e.g., Rosas et al., 2008; Pereira et al., 2017; Gutiérrez-Alonso, 2018; Ferreira et al., 2019; this study). Proposed exhumation mechanisms include large-scale crustal folding and thrusting, transcurrent motion along shear zones, upward flow of buoyant material, and horizontal spreading along crustal detachments. Our new data on deformed samples from the Ossa-Morena Zone record ductile stretching consistent with $\mathrm{N}-\mathrm{S}$ extension and very fast uplift, here interpreted as a brief episode of Variscan intra-orogenic collapse around 335-330 Ma (E1 in Fig. 2). In contrast, most granites crystallized between ca. 325 and 305 Ma record ductile stretching and significant uplift consistent with deformation along NW-SE to ENE-WSW shear zones during 580 late-Variscan compression (C3). This supports a significant stress change around 330-325 Ma, 581 at least in this part of Iberia, and suggests that contrasted styles of tectonic deformation 582 (extensional vs transpressional) can equally promote significant rapid uplift/exhumation of the 583 lower crust within only a few Ma. These characteristics may additionally constitute a unique 584 witness of a (diachronic?) change in deformation style from extension-dominated to 585 transpression-dominated across the orogen.

(3) Late Carboniferous to early Permian tectonic exhumation associated with the final 587 gravitational collapse of the Variscan Orogen (e.g., Burg et al., 1995, Marques et al., 2002). 588 This stage involved significant crustal thinning through transtensional and extensional 589 deformation along low-angle detachments. Related decompression triggered significant 590 partial melting of the lower crust (anatexis), presently witnessed by migmatite domes and 591 late-orogenic anatectic granites, often intruded by younger post-orogenic granites. These 592 various types of rocks are presently exposed in many places of the Variscan Orogen, e.g., in 593 the South Armorican Domain (Turillot et al., 2011; Ballouard et al., 2015), in the French 594 Massif Central (Chardon et al., 2020; Vanderhaeghe et al., 2020), in Italy (Ayuso et al., 1994), 
595 in the Pyrenees (Maurel et al., 2004), and in Iberia (references above; this study). In most 596 instances, available $\mathrm{U}-\mathrm{Pb}, \mathrm{Rb}-\mathrm{Sr}$ and ${ }^{40} \mathrm{Ar} /{ }^{39} \mathrm{Ar}$ ages on amphiboles and micas suggest 597 significant exhumation until at least $290 \mathrm{Ma}$ (Turillot et al., 2011; Chardon et al., 2020). 598 Nevertheless, ${ }^{40} \mathrm{Ar} /{ }^{39} \mathrm{Ar}$ data on feldspars are very scarce (e.g. Maurel et al., 2004), limiting 599 our knowledge of subsequent shallow exhumation dynamics at the full scale of the orogen. 600 Our new MDD data on samples 107X and 107 AC from the Central Iberian Zone have 601 recorded significant cooling and exhumation between ca. 300 and 285 Ma. While the period 602 300-295 Ma coincides with late sinistral movement along main shear zones in the Central 603 Iberian Zone (see previous point), exhumation in the range 295-285 Ma may more 604 realistically be related to (the onset of?) transtension and extension processes associated with 605 the final collapse of the chain (E3 in Fig. 2). Such possibility is supported by the presence of 606 dyke swarms with sharp contacts (chilled margins) and brittle faults with normal-dextral 607 kinematics affecting our samples $107 \mathrm{X}$ and 107AC, respectively (see Table 1).

(4) Late exhumation driven by either Alpine tectonics $(s l)$, or denudation by erosion processes. The thermal influence of the Alpine cycle related to Triassic early extension and opening and closure of the Tethys has been recorded for instance in the central Serbo-

611 Macedonian Massif in the Carpathians (e.g., Antic et al., 2017). Regarding Iberia, recent 612 Apatite Fission Track (AFT) data on siliciclastic sediments filling Mesozoic basins along the 613 western margin of Iberia support significant uplift of the Newfoundland-Iberia rift shoulder 614 following the opening of the Atlantic at ca. $150 \mathrm{Ma}$ (Barbarand et al., 2021). However, the 615 granites studied here are located further to the East of the margin. In fact, AFT data on our 616 samples $107 \mathrm{~T}$ and 107AC show continuous cooling since granite emplacement. Our new 617 MDD data on K-feldspars of the four tested samples from the various structural zones support 618 very slow cooling rates (only a few ${ }^{\circ} \mathrm{C} / \mathrm{Ma}$ ) between 275 and $250 \mathrm{Ma}$. This is consistent with 
Louis granite in the Eastern Pyrenees, though the latter rate has been estimated on a much

621 larger temporal window between 295 and $60 \mathrm{Ma}$ (Maurel et al., 2004). The relatively low cooling rates here obtained for the Central Iberian Zone are interpreted as evidence for slow exhumation driven by passive denudation and isostatic re-adjustment immediately after the 624 collapse of the orogen.

To summarize, our data recorded the successive stages of exhumation associated with

626 the main steps of evolution of the Variscan belt following early continental collision. The 627 combined use of new structural data, $\mathrm{K}-\mathrm{Ar}$ and ${ }^{40} \mathrm{Ar} /{ }^{39} \mathrm{Ar}$ ages on micas, and K-feldspars 628 thermochronology, along with available $\mathrm{U}-\mathrm{Pb}$ ages support a major role of the various 629 tectonic processes over a cumulative period of about $50 \mathrm{Myr}$, followed by much slower 630 evolution driven by passive denudation. Such a scenario is consistent with cooling histories 631 depicted by similar geochronological and ${ }^{40} \mathrm{Ar} /{ }^{39} \mathrm{Ar}$ thermochronological studies on other 632 orogens. For the Cretaceous Gangdese batholith emplaced in Southeastern Tibet during 633 Tethys subduction, mean rates of about $25^{\circ} \mathrm{C} / \mathrm{Myr}$ have been recorded from about 900 to $634300{ }^{\circ} \mathrm{C}$ (Quidelleur et al., 1997), in relation to the high slip rate of $7 \mathrm{~mm} / \mathrm{yr}$ modelled for the 635 Gangdese Thrust (Harrison et al., 2000). Such fast tectonic exhumation rates have also been 636 inferred for older orogens. During the Mesoproterozoic Albany-Fraser Orogen (Western 637 Australia), rapid exhumation driven by transpressional tectonic activity induced high cooling 638 rate, up to $30{ }^{\circ} \mathrm{C} / \mathrm{Myr}$ from 585 to $365^{\circ} \mathrm{C}$ (Scibiorski et al., 2015). For the Eburnean Orogen 639 in the West African Craton, Paleoproterozoic granites record relatively high cooling rates up 640 to $20{ }^{\circ} \mathrm{C} / \mathrm{Myr}$ from 900 to $300{ }^{\circ} \mathrm{C}$ (Sagna et al., 2021). In contrast, much lower cooling rates 641 of only a few ${ }^{\circ} \mathrm{C} / \mathrm{Myr}$ have been inferred for the Grenville Orogen over the $500-350{ }^{\circ} \mathrm{C}$ 642 (Reynolds et al., 1995) and 500-150 ${ }^{\circ} \mathrm{C}$ (Cosca et al., 1991) temperature ranges, suggesting 643 that exhumation was there mainly controlled by post-orogenic erosional unroofing. 


\section{Conclusions}

Our combined $\mathrm{K}-\mathrm{Ar}$ and ${ }^{40} \mathrm{Ar} /{ }^{39} \mathrm{Ar}$ geochronological and thermochronological study of

647 granites from various portions of the Variscan orogen in western Iberia shows that:

- Granites crystallized at ca. $335 \mathrm{Ma}$ in the Ossa-Morena Zone have recorded mostly ductile stretching (L-tectonites striking around N-S), consistent with N-S extension associated with Variscan intra-orogenic collapse. The small age difference between U$\mathrm{Pb}, \mathrm{K}-\mathrm{Ar}$ and ${ }^{40} \mathrm{Ar} /{ }^{39} \mathrm{Ar}$ ages on these granites supports relatively fast cooling associated with rapid tectonic exhumation. and $\mathrm{K}-\mathrm{Ar}$ and ${ }^{40} \mathrm{Ar} /{ }^{39} \mathrm{Ar}$ ages. This supports crystallization at deep level in the core of the chain, followed by a long-cooling history associated with significant exhumation by tectonics processes: fast tectonic exhumation between ca $315 \mathrm{Ma}$ and $285 \mathrm{Ma}$, due to (1) non purely-horizontal left-lateral movement along shear zones during the end of C3, and (2) late extension during the final collapse of the Variscan orogen (E2). Central Iberian zones have recorded mostly isotropic strain (no visible ductile foliation or lineation) and show no significant offset between $\mathrm{U} / \mathrm{Pb}$ and ${ }^{40} \mathrm{Ar} /{ }^{39} \mathrm{Ar}$ ages. This supports shallow granite emplacement, during E2, and subsequent low-rate denudation and isostatic rebound.

- Our new K-Ar and ${ }^{40} \mathrm{Ar} /{ }^{39} \mathrm{Ar}$ data, along with available U-Pb, support a northward propagation of tectonic exhumation from the Ossa-Morena Zone to the Central Iberian Zone. significant ore-deposits formation with tin deposits occurring in pegmatites and/or quartz veins associated with the muscovite-rich syn-C3 granites and those of tungsten 

granites.

672

\section{Acknowledgments}

674 Constructive remarks by two reviewers (J.R. Martínez Catalán and anonymous

675 reviewer) and by the Editor helped to significantly improve the quality of the manuscript.

676 Thanks to L. Hughes-Allen for careful reading and useful suggestions regarding the English.

677 This study was supported by research project TEAMINT (POCTI/CTE/48137/2002) and

678 project UIDB/04683/2020-ICT (Institute of Earth Sciences) supported by the Portuguese

679 Foundation for Science and Technology (FCT), and internal funding. This is LGMT

680 contribution 165.

681

682 Declaration of interest

683 The authors declare that they have no known competing financial interests or personal

684 relationships that could have appeared to influence the work reported in this paper.

685

686 


\section{References}

688 Abalosa, B., Ibarguchi, J.I.G., Eguiluz, L., 1991. Cadomian subduction/collision and Variscan 689 transpression in the Badajoz-Córdoba shear belt, southwest Spain. Tectonophysics, 199, 690 $51-72$.

691 Antic', M.D., Kounov, A., Trivic', B., Spikings, R., Wetzel, A., 2017. Evidence of Variscan and Alpine tectonics in the structural and thermochronological record of the central Serbo - Macedonian Massif (south - eastern Serbia). Int J Earth Sci (Geol Rundsch) (2017) 106:1665-1692.

Antunes, I. M. H. R. ,Neiva, A.M.R., Corfu, F., 2012. U-Pb Early Ordovician emplacement ages and K-Ar Variscan recrystallization ages of the Fundão granitic pluton, central Portugal. European Mineralogical Conference, Vol. 1, EMC2012-747.

Barbarand, J., Marques, F.O., Hildenbrand, A., Pinna Jamme, R., Nogueira, C.R., 2021. Thermal evolution of onshore west Iberia: towards a better constraint of the age of breakup in the Iberia-Newfoundland Atlantic. Tectonophysics, in revision.

Bea, F., Montero, P., Molina, J.F., 1999. Mafic precursors, peraluminous granitoids, and late lamprophyres in the Avila batholith; a model for the generation of Variscan batholiths in Iberia. J. Geol. 107, 399-419.

Bobos, I., Gonçalves, A.M., Lima, L., Noronha, F., 2019. Micas 40Ar/39Ar dating of hydrothermal events related with the post-orogenic $\mathrm{W}( \pm \mathrm{Sn}),(\mathrm{Cu}, \mathrm{Mo})$ mineralization from Borralha, Northern Portugal. Life with Ore Deposits on Earth - proceedings of the 15th SGA Biennial Meeting 2019, Glasgow (Scotland) vol 1, 353-356.

Boiron, M.-C., Cathelineau, M., Banks, D.A., Yardley, B., Noronha, F., Miller, M.F., 1996. P-T-X conditions of late Hercynian fluid penetration and the origin of granite-hosted gold quartz veins in northwestern Iberian: a multidisciplinary study of fluid inclusions and their chemistry. Geochim Cosmochim. Acta, 60, 43-57. 
712 Burg, J.P., Van den Driessche, Brun, J.P., 1994. Syn- to post-thnickening extension in teh

713 Variscan Belt of Western Europe: Modes and structural consequences. Géologie de la $714 \quad$ France, 3, 33-51.

715 Capdevila R, Corretge LG, Floor P, 1973. Les granitoïdes Varisques de la Meseta Ibérique.

$716 \quad$ Bull Soc Geol Fr 15: 209-228.

717 Carrilho Lopes, J., Sant'Ovaia, H., Martins, H.C.B., Nogueira, P., Lopes, L., 2016. U-Pb

718 geochronology and $\mathrm{Nd}$ isotope contributions to the interpretation of a peculiar ring massif:

719 the Santa Eulália plutonic complex (SW Iberia, Portugal). GEO - Comunicações - Em

$720 \quad$ Congressos Científicos Internacionais 149.

721 Carocci, E., Marignac, C., Cathelineau, M., Truche, L., Lecomte, A., Pinto, F., 2019. Rutile

722 from Panasqueira (Central Portugal): An Excellent Pathfinder for Wolframite Deposition.

723 Minerals 2019, 9, 9; doi:10.3390/min9010009.

724 Cassignol, C., Gillot, P. Y., 1982. Range and effectiveness of unspiked potassium-argon

725 dating: experimental groundwork and applications. Numerical dating in stratigraphy 1, 726 159-179, John Wiley, New York.

727 Chardon, D., Aretz, M., Roques, D., 2020. Reappraisal of Variscan tectonics in the southern $728 \quad$ French Massif Central. Tectonophysics, 787, 228477.

729 Cherniak, D.J., Watson, E.B., 2000. Pb diffusion in zircon. Chem. Geol., 172, 5-24.

730 Chichorro, M., Pereira, M.F., Díaz-Azpiroz, M., Williams, I.S., Fernández, C., Pin, C., Silva, 731 J.B., 2008. Cambrian ensialic rift-related magmatism in the Ossa-Morena Zone (Évora732 Aracena metamorphic belt, SW Iberian Massif): Sm-Nd isotopes and SHRIMP zircon U$733 \mathrm{Th}-\mathrm{Pb}$ geochronology. Tectonophysics, 461, 9-113.

734 Clark $\mathrm{AH}, 1970$. Potassium-argon ages and regional relationships of the Panasqueira 735 tintungsten mineralization. Comun Serv Geol Port 54: 243-261. 
Cosca, M. A., Sutter, J. F., \& Essene, E. J. (1991). Cooling and inferred uplift/erosion history of the Grenville Orogen, Ontario: constraints from ${ }^{40} \mathrm{Ar} /{ }^{39} \mathrm{Ar}$ thermochronology. Tectonics, 10(5), 959-977.

Coulié E., X. Quidelleur, J.C. Lefèvre and P.Y. Gillot, 2004. Exploring the multicollection approach for the 40Ar/39Ar dating technique. Geochem. Geophys. Geosyst., 5, Q11010, doi:10.1029/2004GC000773.

Dallmeyer R.D., Ribeiro, A., Marques, F.O., 1991. Polyphase Variscan emplacement of exotic terranes (Morais and Bragança Massifs) onto Iberian successions: Evidence from ${ }^{40} \mathrm{Ar} /{ }^{39} \mathrm{Ar}$ mineral ages. Lithos 27(2), 133-144.

Dias, G., Leterrier, J., Mendes, A., Simoes, P.P., Bertrand, J.M., 1998. U-Pb zircon and monazite geochronology of post-collisional Hercynian granitoids from the Central Iberian

748 Zone Northern Portugal. Lithos, ,45, 349-369.

Dias, G., Simões, P.P., Ferreira, N., Leterrier, J., 2002. Mantle and crustal sources in the genesis of Late-Hercynian granitoids (NW Portugal): geochemical and $\mathrm{Sr}-\mathrm{Nd}$ isotopic constraints. Gondwana Res. 5(2), 287-305.

Farias, P.; Gallastegui, G.; Gonzalez Lodeiro, F.; Marquinez, J.; Martin Parra, L.M.; Martínez Catalan, J.R.; de Pablo Maciá, J.G.; Rodriguez Fernandez, L.R. 1987. Aportaciones al Conocimiento de la Litoestratigrafia y Estructura de Galícia Central. Mem. Museu Laboratório Mineralogia Geologia da Faculdade Ciências Universidade Porto; 1, 411-431.

Ferreira, J.A., Bento dos Santos, T., Pereira, I., Mata, J., 2019. Tectonically assisted exhumation and cooling of Variscan granites in an anatectic complex of the Central Iberian

Zone, Portugal: constraints from LA-ICP-MS zircon and apatite U-Pb ages. International Journal of Earth Sciences, 108, 2153-2175.

Ferreira, N., Iglésias, M., Noronha, F., Pereira, E., Ribeiro, A., Ribeiro, M.L., 1987.

760 Granitóides da zona Centro-Ibérica e seu enquadramento geodinâmico. In: Bea, F., 

granitoides y rocas asociadas del Macizo Hespérico. Libro Homenage a L.C.G.Figueirola. Editorial Rueda, Madrid, pp. 37-53.

764

Fleck, R.J., Sutter, J.F., Elliot, D.H., 1977. Interpretation of discordant ${ }^{40} \mathrm{Ar} /{ }^{39} \mathrm{Ar}$ age-spectra of Mesozoic tholeites from Antarctica. Geochem. Cosmochem. Acta, 41, 15-32.

Franek, J., Schulmann, K., Lexa, O., Tomek, C., Edel, J.B., 2011. Model of syn-convergent extrusion of orogenic lower crust in the core of the Variscan belt: implications for exhumation of high-pressure rocks in large hot orogens. J. Metamorphic Geol., 29, 53-78, doi.org/10.1111/j.1525-1314.2010.00903.x

Franke, W., 2000. The mid-European segment of the Variscides: tectonostratigraphic units, terrane boundaries and plate tectonic evolution. In: Franke, W., Haak, V., Oncken, O., Tanner, D. (eds), Orogenic Processes: Quantification and Modelling in the Variscan Belt. Geological Society, London, Special Publications 179, 35-61.

Fuhrmann, U., Lippolt, H.J., Hess, J.C., 1987. Examination of some proposed K-Ar standards: ${ }^{40} \mathrm{Ar} /{ }^{39} \mathrm{Ar}$ analyses and conventional $\mathrm{K}-\mathrm{Ar}$ data. Chemical Geology $66,41-51$.

Gébelin, A., Roger, F., Brunel, M., 2009. Syntectonic crustal melting and high-grade metamorphism in a transpressional regime, Variscan Massif Central, France. Tectonophysics, 477, 229-243.

Gerbault, M., Schneider, J., Reverso-Peila, A., Corsini, M., 2018. Crustal exhumation during ongoing compression in the Variscan Maures-Tanneron Massif, France-Geological and thermo-mechanical aspects. Tectonophysics, 746, 439-458.

Gillot, P.Y. \& Cornette, Y., 1986. The Cassignol technique for potassium-argon dating, precision and accuracy - examples from the Late Pleistocene to recent volcanics from southern Italy. Chem. Geol. 59, 205-222. 
Gillot, P.Y., Cornette, Y., Max, N., Floris, B., 1992. Two reference materials, trachytes MDO-G and ISH-G, for argon dating ( $\mathrm{K}-\mathrm{Ar}$ and Ar-40/Ar-39) of Pleistocene and Holocene rocks. Geostandards Newsletter 16, 55-60.

Gillot, P.Y., Hildenbrand, A., Lefevre, J.C., \& Albore-Livadie, C., 2006. The K-Ar dating method: principle, analytical techniques, and application to Holocene volcanic eruptions in Southern Italy. Acta Vulcanol. 18, 55-66.

Gutiérrez-Alonso G. Fernández-Suárez J., López-Carmona Alicia and Gärtner Andreas, 2018. Exhuming a cold case: The early granodiorites of the northwest Iberian Variscan belt-A Visean magmatic flare-up? LITHOSPHERE; v. 10; no. 2; p. 194-216.

Harrison, T. M., Yin, A., Grove, M., Lovera, O. M., Ryerson, F. J., \& Zhou, X. (2000). The Zedong Window: A record of superposed Tertiary convergence in southeastern Tibet. J. Geophys. Res. (Solid Earth), 105 (B8), 19211-19230.Hawkesworth, C., Cawood, P.A., Dhuime, B., 2019. Rates of generation and growth of the continental crust, Geoscience Frontiers 10 (1), doi.org/10.1016/j.gsf.2018.02.004

Holmes, A., 1946. An estimate of the age of the Earth. Nature, 157, 680-684.

Houtermans, F. G., 1946. Die Isotopenhaüfigkeiten im naturlichen Blei und das Alter des Urans. Naturwiss., 33, p. 185-186.

Iglesias, M., Ribeiro, A., 1981. Zones de cisaillement ductile dans l'arc ibéro-armoricain. Comun. Serv. Geol. Port. 67, 85-87.

Jaques, L., Noronha, F., Liewig, N., Bobos, I., 2016. Paleofluids circulation associated with the Gerês late-orogenic granitic massif, northern Portugal. Geochemistry, 76 (4), 659-676.

Julivert, M., Fontboté, J., Ribeiro, A., Conde, L., 1974. Mapa tectonico de la Penınsula Iberica y Baleares, escala 1/1,000,000. Inst. Geol. Min. Espana, 113 pp.

Korchinsky, M., Rey, P.F., Mondy, L., Teyssier, C., Whitney, D.L., 2018. Numerical investigation of deep-crust behavior under lithospheric extension. Tectonophysics 726, 
$137-146$.

811 Kuiper, K. F., Deino, A., Hilgen, F. J., Krijgsman, W., Renne, P. R., Wijbrans, J. R. (2008).

812 Synchronizing Rock Clocks of Earth History. Science 320: doi: 10.1126/science.1154339. 813 issn: 0036-8075.

814 Ireland, T.R., Clement, S., Compston, W., Foster, J.J., Holden, P., Jenkins, B., Lanc, P., 815 Schram, N., Williams, I.S., 2008. Development of SHRIMP, Australian Journal of Earth $816 \quad$ Sciences, 55:6-7, 937-954.

817 Launay, G., 2018. Hydrodynamique des systèmes minéralisés péri-granitiques : étude du 818 gisement à W-Sn-(Cu) de Panasqueira (Portugal). PhD thesis. Univ. Orléans (France), p. 819506.

820 Lee, J.K.W., Williams, I.S., Ellis, D.J., 1997. Pb, U and Th diffusion in natural zircon. Nature $821390,159-162$.

822 Symposium on Granitic Pegmatites, Bartlett, United States. PEG 2013:77-78.

823 Lima, S.M., Corfu, F., Neiva, A.M.R., Ramos, J.M.F., 2012. Dissecting Complex Magmatic

824 Processes: an in-depth U-Pb Study of the Pavia Pluton, Ossa^Morena Zone, Portugal. J. $825 \quad$ Petrol., 53, 9, 1887-1911.

826 Lima A, Mendes L, Melleton J, Gloaguen E, Frei D, 2013. Seixoso-Vieiros Rare Element 827 Pegmatite Field: Dating the Mineralizing Events. PEG 2013: The 6th International

828 LNEG, 1992 - Geological map of Portugal scale 1:500,000.

829 Lopes, J.C., Sant'Ovaia, H., Martins, H.C.B., Nogueira, P., Lopes, L. 2016. U-Pb 830 geochronology and $\mathrm{Nd}$ isotope contributions to the interpretation of a peculiar ring massif: 831 the Santa Eulália plutonic complex (SW Iberia, Portugal). Abstracts of the 35th 832 International Geological Congress, Cape Town, South Africa.

833 Lovera, O.M., Richter, F.M., \& Harrison, T.M., 1989. ${ }^{40} \mathrm{Ar} /{ }^{39} \mathrm{Ar}$ geothermometry for slowly 834 cooled samples having a distribution of diffusion domain sizes. Journal of Geophysical 
Research, 94, 17917-17935.

836 Lovera, O.M., 1992. Computer programs to model ${ }^{40} \mathrm{Ar} /{ }^{39} \mathrm{Ar}$ diffusion data from multi-

837 domain samples. Computers and Geosciences, 18, 789-813.

838 Lovera, O.M., Grove, M., Harrison, T.M., \& Mahon, K.I., 1997. Systematic analysis of K 839 feldspar Ar/Ar step-heating experiments I: Significance of activation energy 840 determinations. Geochim. Cosmochim. Acta, 61, 3171-3192.

841 Lee J.K.W., Williams, I.S., Ellis, D.J., 1997. Pb, U and Th diffusion in natural zircon. Nature 842 $390,159-162$.

843 Marques, F.O., Mateus, A., Tassinari, C., 2002. The Late-Variscan fault network in central844 northern Portugal (NW Iberia): a re-evaluation. Tectonophysics 359, 255-270.

845 Marques de Sá C., Noronha F., Cardellach E., Bobos I. 2019. Fluid inclusion and (S, C, O, $846 \mathrm{~Pb})$ isotope study of $\mathrm{Pb}-\mathrm{Zn}-(\mathrm{Cu}-\mathrm{Ag})$ hydrothermal veins from Central and Northern 847 Portugal - Metallogenic implications. Ore Geology Reviews 112, 1-15

848 Martínez Catalán, J.R., Rubio Pascual, F.J., Montes, A.D., Fernández, R.D., Barreiro, J.G., 849 Dias Da Silva, Í., Clavijo, E.G., Ayarza, P., Alcock, J.E., 2014. The late Variscan HT/LP 850 metamorphic event in NW and Central Iberia: relationships to crustal thickening, extension, 851 orocline development and crustal evolution. Geological Society, London, Special 852 Publications 405, 225-247.

853 Marzoli, A., Renne, P. R., Piccirillo, E. M., Ernesto, M., Bellieni, G., \& De Min, A. (1999). 854 Extensive 200-million-year-old continental flood basalts of the Central Atlantic Magmatic 855 Province. Science, 284, 616-618.

856 Mateus, A., Noronha, F., 2010. Sistemas mineralizantes epigenéticos na Zona Centro-Ibérica; 857 expressão da estruturação orogénica Meso-a Tardi-Varisca. Ciências Geológicas-Ensino e 858 Investigação e sua história. Volume II, Geologia Aplicada, 47-61. 
Matte, P., 1991. Accretionary history and crustal evolution of the Variscan belt in Western Europe. Tectonophysics 196, 309-337.

861

Maurel, O., Respaut, J. P., Monié, P., Arnaud, N., \& Brunel, M., 2004. U/Pb emplacement and ${ }^{40} \mathrm{Ar} /{ }^{39} \mathrm{Ar}$ cooling ages of the eastern Mont-Louis granite massif (Eastern Pyrenees, France). Comptes Rendus Geoscience, 336(12), 1091-1098.

McDougall, I., T.M. Harrison, 1999. Geochronology and thermochronology by the ${ }^{40} \mathrm{Ar} /{ }^{39} \mathrm{Ar}$ method, Oxford Univ. Press, New York, 269 pp.

Mendes, A., Dias, G., 2004. Mantle-like Sr-Nd isotope composition of Fe-K subalkaline granites: the Peneda-Gerês Variscan massif (NW Iberian Peninsula). Terra Nova, vol. 16, no. 3, pp. 109-115.

Moita P, Munhá J, Fonseca P, Tassinari C, Araújo A, Palácios T 2005a).Dating orogenic events in Ossa-Morena Zone. Actas do XIV Semana de Geoquímica/VIII Congresso de Geoquímica dos Países de Língua Portuguesa, 459-462.

Moita P, Munhá J, Fonseca P, Tassinari C, Araújo A, Palácios T., 2005b) Phase equilibria and geochronology of Ossa-Morena eclogites. In: XIV Semana de Geoquímica/VIII Congresso de Geoquímica dos Países de Língua Portuguesa. pp 463-466.

Moura A, Dória A, Neiva A.M.R, Leal Gomes C, Creaser R.A, 2014. Metallogenesis at the Carris W-Mo-Sn deposit (Gerês, Portugal): Constraints from fluid inclusions, mineral geochemistry, Re-Os and He-Ar isotopes. Ore Geol. Rev., 56:73-93.

Murphy, J.B., Quesada, C., Gutiérrez-Alonso, G., Johnston, S.T., Weil, A., 2016. Reconciling competing models for the tectono-stratigraphic zonation of the Variscan orogen in western Europe. Tectonophysics 681, 209-219. 
Nabelek, P.I., Hofmeister, A.M., Whittington, A.G., 2012. The influence of temperaturedependent thermal diffusivity on the conductive cooling rates of plutons and temperaturetime paths in contact aureoles. Earth Planet. Sci. Lett., 317-318, 157-164.

Neiva, A. M. R.,1984. Geochemistry of tin-bearing granitic rocks. Chem. Geol., 43, 241-256.

Neiva, A. M. R., 2002. Portuguese granites associated with Sn-W and Au mineralizations. Bulletin of the Geological Society of Finland, 74, 79-101.

Neiva, A.M.R., Williams, I.S., Lima, S.M., Teixeira, R.J.S., 2012. U-Pb and 39Ar/40Ar data constraining the ages of the source, emplacement and recrystallization/cooling events from late- to post-D3 Variscan granites of the Gouveia area, central Portugal. Lithos, 153, 72-83.

Nier, 1A.O., Thompson, R.W., Murphey, B.F., 1941. The isotopic composition of lead and the measurement of geologic Time III. Phys. Rev., 60, 112-116.

Nomade, S., Knight, K.B., Beutel, E., Renne, P., 2007. Chronology of the Central Atlantic Magmatic Province: Implications for the Central Atlantic rifting processes and the Triassic-Jurassic biotic crisis. Palaeogeography Palaeoclimatology Palaeoecology, 244 (1), 326-344.

Noronha, F., Vindel, E., López, J.A., Dória, A., Garcia, E., Boiron, M.-C., Cathelineau, M., 1999. Fluids related to tungsten ore deposits in Northern Portugal and Spanish Central System: a comparative study. Rev. Soc. Geol. España, vol. 12, pp. 397-403.

Noronha F., Ribeiro M. A., Almeida A., Dória A., Guedes A., Lima A., Martins H. C, Sant'Ovaia H., Nogueira P., Martins T., Ramos R., Vieira R., 2013. Jazigos filonianos hidrotermais e aplitopegmatíticos espacialmente associados a granitos norte de Portugal. In Geologia de Portugal, Ed: R. Dias, A. Araújo, P. Terrinha \& J. C. Kullberg., Escolar Editora Vol I - Geologia Pré-mesozóica de Portugal. pp. 403-438 
904 Noronha, F., 2017. Fluids and Variscan metallogenesis in granite related systems in Portugal.

905 Procedia Earth and Planetary Science, 17, 1-4.

906 Orejana, D., Villaseca, C., Perez-Soba, C., Lopez-Garcia, J.A., Billstrom, K., 2009. The 907 Variscan gabbros from the Spanish Central System: A case for crustal recycling in the sub908 continental lithospheric mantle? Lithos, 110 (1-4), 262-276.

909 Pereira, I., Dias, R., Bento dos Santos, T., Mata J., 2017. Exhumation of a migmatite complex 910 along a transpressive shear zone: inferences from the Variscan Juzbado-Penalva do 911 Castelo Shear Zone (Central Iberian Zone). J. Geol. Soc. Lond., 174, 1004-1018.

912 Pereira, M.F., Chichorro, M., Moita, P., Santos, J.F., Solá, A.M.R., Williams, I.S., Silva, J.B., 913 Armstrong, R.A., 2015. The multistage crystallization of zircon in calc - alkaline 914 granitoids: $\mathrm{U}-\mathrm{Pb}$ age constraints on the timing of Variscan tectonic activity in SW Iberia. 915 Int J. Earth Sci. (Geol. Rundsch.), 104, 1167-1183.

916 Pereira, M.F., Díez Fernández, R., Gama, C., Hofmann, M., Gärtner, A., Linnemann, U., 2018. $917 \quad \mathrm{~S}$ - type granite generation and emplacement during a regional switch from extensional to 918 contractional deformation (Central Iberian Zone, Iberian autochthonous domain, Variscan 919 Orogeny), Int. J. Earth. Sci., 107:251-267.

920 Phillips, D., Matchan, E.L., Honda, M., Kuiper, K.F., 2017. Astronomical calibration 921 of ${ }^{40} \mathrm{Ar} /{ }^{39} \mathrm{Ar}$ reference minerals using high-precision, multi-collector (ARGUSVI) mass 922 spectrometry. Geochem. Cosmochem. Acta, 196, 351-389.

923 Priem, H.N.A, den Tex, E., 1984. Tracing crustal evolution in the NW Iberian Peninsula 924 through the $\mathrm{Rb} / \mathrm{Sr}$ and $\mathrm{U}-\mathrm{Pb}$ systematics of Palaeozoic granitoids: a review. Physics of the 925 Earth and Planetary Interiors, 35 (1-3), 121-130. 
Quesada, C., 1991. Geological constraints on the Paleozoic tectonic evolution of tectonostratigraphic terranes in the Iberian Massif. Tectonophysics 185, 225-245.

Quidelleur, X., Grove, M., Lovera, O. M., Harrison, T. M., Yin, A., \& Ryerson, F. J., 1997. Thermal evolution and slip history of the Renbu Zedong Thrust, southeastern Tibet. J. Geophys. Res. (Solid Earth), 102(B2), 2659-2679.

Rackzek, I., Stoll, B., Hofmann, A.W. \& Jochum, K.P., 2001. High-precision trace element data for the USGS reference materials BCR-1, BCR-2, BHVO-1, BHVO-2, AGV-1, AGV-2, DTS-1, DTS-2, GSP-1 and GSP-2 by ID-TIMS and MIC-SSMS. Geostandards Newsletter 25, 77-86.

Rey, P., Vanderhaeghe, O, Teyssier, C., 2001. Gravitational collapse of the continental crust: definition, regimes and modes. Tectonophysics, 342, 435-449.

Reynolds, P. H., Culshaw, N. G., Jamieson, R. A., Grant, S. L., \& McKenzie, K. J., 1995. ${ }^{40} \mathrm{Ar} /{ }^{39} \mathrm{Ar}$ traverse - Grenville Front Tectonic Zone to Britt Domain, Grenville Province, Ontario, Canada. Journal of Metamorphic Geology, 13(2), 209-221.

Ribeiro, M.L., Reche, J., López-Carmona, A., Aguilar, A.C., Bento dos Santos, T., Chichorro, M., Dias da Silva, Í., Díez-Montes, A., González-Clavijo, E., Gutiérrez-Alonso, G., Leal, N., Liesa, M., Martínez, F.J., Mateus, A., Mendes, M.H., Moita, P., Pedro, J., Quesada, C., Santos, J.F., Solá, A.R., Valverde-Vaquero, P., 2019. Variscan metamorphism. In C. Quesada and J.T. Oliveira (eds.), The Geology of Iberia: A Geodynamic Approach, Regional Geology Reviews, Springer Nature Switzerland AG 2019. https://doi.org/10.1007/978-3-030-10519-8

Ricci J., Quidelleur X., Pavlov V., Orlov S., Shatsillo A. and Courtillot V., 2013. New 40Ar/39Ar and K-Ar ages of the Viluy traps (Eastern Siberia): Further evidence for a relationship with the Frasnian-Famennian mass extinction. Palaeogeography, 
951 Rosas, F., Marques, F., Ballèvre, M., Tassinari, C., 2008. Geodynamic evolution of the SW 952 Variscides: Orogenic collapse shown by new tectonometamorphic and isotopic data from 953 western Ossa-Morena Zone, SW Iberia. Tectonics 27, TC6008, doi:10.1029/ 954 2008 TC002333.

955

Roth, E., Pothy, B., 1985. Méthodes de datation par les phénomènes nucléaires. Applications. Masson, coll. CEA, 631pp.

Sagna I., Quidelleur X., NDiaye F., Gillot P.Y., Lefèvre J.C., Dioh E., 2017. K-Ar mineral ages and thermal history of magmatic and metamorphic Paleoproterozoic units from the northern part of Kedougou inlier, West African Craton (eastern Senegal). Geological Journal, 52, 207-216. DOI: 10.1002/gj.2749.

Sagna, I., Quidelleur, X., Dioh, E., Gillot, P. Y., Lefèvre, J. C., Baratoux, L., \& Diallo, D. P., 2021. Proterozoic magmatic events recorded in 40Ar/39Ar data from the northern part of the Kedougou Kenieba Inlier (eastern Senegal). Journal of African Earth Sciences, 175, 104109.

Schwarz, W.H., Trieloff, M., 2007. Intercalibration of ${ }^{40} \mathrm{Ar} /{ }^{39} \mathrm{Ar}$ age standards NL-25, HB3gr hornblende, GA1550, SB-3, HD-B1 biotite and BMus/2 muscovite. Chemical Geology $242,218-231$.

Scibiorski, E., Tohver, E., \& Jourdan, F., 2015. Rapid cooling and exhumation in the western part of the Mesoproterozoic Albany-Fraser Orogen, Western Australia. Precambrian Research, 265, 232-248.

Schermerhorn, L.J.G,1981. Framework and evolution of Hercynian mineralization in the Iberian Meseta. Leidse Geol. Medelelingen 1981, 52, 23-56.

Simancas, J.F., Tahiri, A., Azor, A., González Lodeiro, F., Martínez Poyatos, D., El Hadi, H., 
2005. The tectonic frame of the Variscan-Alleghanian Orogen in Southern Europe and

$975 \quad$ Northern Africa. Tectonophysics 398, 181-198.

976 Snee, L.W., Sutter, J.F., Kelly, W.C., 1988. Thermochronology of economic mineral deposits; 977 dating the stages of mineralization at Panasqueira, Portugal, by high-precision ${ }^{40 / 39}$ Ar age 978 spectrum techniques on muscovite. Economic Geology, 83 (2): 335-354.

979 Solá, A.R., Williams, I.S., Neiva, A.M.R., Ribeiro, M.L., 2009. U-Th-Pb SHRIMP ages and 980 oxygen isotope composition of zircon from two contrasting late Variscan granitoids, Nisa981 Albuquerque batholith, SW Iberian Massif: Petrologic and regional implications. Lithos, 982 $111(3-4), 156-167$.

983 Steiger, R.H., Jager, E., 1977. Subcommission on geochronology: convention on the use of 984 decay constants in geo and cosmochronology. Earth Planet. Sci. Lett. 36, 359-362.

985 Tartese, R., Ruffet, G., Poujol, M., Boulvais, P., Ireland, T.R., 2011. Simultaneous resetting 986 987 of the muscovite $\mathrm{K}-\mathrm{Ar}$ and monazite U-Pb geochronometers: a story of fluids. Terra Nova, 23 (6), 390-398.

Turillot, P., Augier, R., Monié, P., Faure, M., 2011. Late orogenic exhumation of the Variscan 989 high - grade units (South Armorican Domain, western France), combined structural and 40Ar/39Ar constraints. Tectonics, 30, doi:10.1029/2010TC002788.

Valle Aguado, B., Azevedo, M.R., Schaltegger, U., Martınez Catalan, J.R., Noland, J., 2005. $\mathrm{U}-\mathrm{Pb}$ zircon and monazite geochronology of Variscan magmatism related to synconvergence extension in Central Northern Portugal. Lithos 82, 169-184.

994 Vanderhaeghe, O., Teyssier, C., 2001. Crustal-scale rheological transitions during late$995 \quad$ orogenic collapse. Tectonophysics 335 (1), 211-228.

996 Vieira, R., Roda-Robles, E., Pesquera, A., Lima, A., 2011. Chemical variation and 997 significance of micas from the Fregeneda-Almendra pegmatitic field (Central-Iberian 

Zone, Spain and Portugal). American Mineralogist, 96 (4), 637-645.

Vigneresse J.L., 1999. Intrusion level of granitic massifs along the Hercynian belt: balancing the eroded crust. Tectonophysics, 307, 277-295.

Villaseca, C., Orejana, D., Belousova, E., Armstrong, R.A., Pérez-Soba, C., Jeffries, T.E., 2011. $\mathrm{U}-\mathrm{Pb}$ isotopic ages and $\mathrm{Hf}$ isotope composition of zircons in Variscan gabbros from central Spain: evidence of variable crustal contamination. Miner. Petrol., 101, 151167.

Zhang, R.Q., Ramos, V., Leal, S., Noronha, F., Pinto, F., 2019. U-Pb geochronology of cassiterites from primary $\mathrm{Sn}$ mineralizations in $\mathrm{Sn}-\mathrm{W}$ Variscan Metallogenic Province, Portugal. Life with ore deposits on Earth, Proceedings of the 15th SGA biennal Meeting, Glasgow (Scotland), 357-360.

\section{Table captions:}

Table 1: Main characteristics of the investigated outcrops and samples. OMZ - Ossa-Morena Zone; CIZ - Central Iberian Zone; GTMZ - Galicia Trás-os-Montes Zone. Symbols and description according to the geological map of Portugal (1/500,000 Geological map of Portugal-LNEG (1992). Zircon U-Pb ages from: (1) Chichorro et al. (2008); (2) Pereira et al. (2015); (3) Lima et al. (2012); (4) Sola et al. (2009); (5) Lopes et al. (2016); (6) Antunes et al. 
1022 (2012); (7) Neiva et al., 2012; (8) Valle-Aguado et al. (2005); (9) Ferreira et al. (2019); (10)

1023 Pereira et al. (2018); (11) Dias et al. (1998). Pre-Variscan ages (inherited zircon) indicated in 1024 Italics. Additional information on previous $\mathrm{U} / \mathrm{Pb}$ ages is provided in Supplement 1.

Table 2: New K-Ar results on the various mineral phases of our samples. Lat.: latitude, Long.:

1027 longitude; KFd: K-Feldspar (only one Ar determination), biot: biotite, musc: muscovite. The 1028 mean age is obtained by weighing by the amount of radiogenic argon $\left({ }^{40} \mathrm{Ar} *\right)$, except in the case of 107D-biot, 107G-biot, and 107J-musc; for the latter, all three individual determinations overlap within uncertainties, and the mean age $(*)$ is calculated by weighing by the inverse of variance. Measured ages in normal font, and mean ages in bold font.

1032 Uncertainties quoted at the $1 \sigma$ level.

1034 Table 3: New ${ }^{40} \mathrm{Ar} /{ }^{39} \mathrm{Ar}$ results on the various mineral phases of our samples. Plateau ages are 1035 given with analytical uncertainties, with the total (i.e. including J-factor error) uncertainty in 1036 parentheses. $\mathrm{n}$ : number of steps included in the plateau; $\mathrm{N}$ : total number of steps

1037 performed. $\%{ }^{39} \mathrm{Ar}$ : cumulative amount of ${ }^{39} \mathrm{Ar}$ included in the plateau. MSWD: mean square 1038 weighted deviates. All uncertainties quoted at the $1 \sigma$ level.

\section{Figure captions:}

1040 Figure 1: Simplified geological map of Portugal showing the various Variscan and pre-

1041 Variscan chrono-stratigraphic units in the main tectonic zones. The position of our dated 1042 samples is reported with black circles. Sample acronyms indicated with bold italic font. 1043 SPZ is South Portuguese Zone, and GTMZ is Galicia-Trás-os-Montes Zone. Main towns 1044 shown with dark blue solid squares; smaller towns and villages shown with white squares 
1045 circled with black. A: Alpalhão, CM: Campo Maior, F: Fundão, G: Guimarães, M: Monforte, 1046 P: Pavia, V: Vendinha.

1048 Figure 2: Tectonic/metamorphic/igneous evolution in the CIZ, GTMZ and OMZ. C stands for 1049 contractional deformation, E for extensional, M for metamorphic, and I for igneous. I1 - Syn1050 kinematic gabbro, granodiorite, and tonalite; I2 - syn-kinematic granite and adamellite; I3 1051 late- to post-kinematic granitoids. Metamorphic grades, tectonic events, and some of the ages 1052 from Martínez Catalán et al. (2014). Subduction to collision age from Moita et al. (2005a, b). 1053 I1 ages 360-330 Ma from Dallmeyer et al. (1993), Rosas et al. (2008), Jesus et al. (2007), Pin 1054 et al. (2008).

Figure $3:{ }^{40} \mathrm{Ar} /{ }^{39} \mathrm{Ar}$ age spectra on biotite and muscovite. Plateau ages shown with double 1057 arrows. Total age uncertainty in brackets.

1059 Figure 4: Comparison between our K-Ar and ${ }^{40} \mathrm{Ar} /{ }^{39} \mathrm{Ar}$ integrated ages.

1061 Figure $5:{ }^{40} \mathrm{Ar} /{ }^{39} \mathrm{Ar}$ age spectra on K-Feldspars of our samples.

1063 Figure 6: Comparison of thermal histories obtained for samples 107AC and 107AS with 1064 MDD inverse and forward modelling (all using an imposed activation energy of $46 \mathrm{kcal} / \mathrm{mol}$, 1065 see supplementary figures 1 and 2 for more detail). Note the overall good agreement between inverse and forward modelling for each sample. 
1068 Figure 7: Comparison of the 4 thermal histories obtained with MDD forward modelling on K-

1069 Feldspars of our samples 107J, X, AC and AS (all using an imposed activation energy of 46

$1070 \mathrm{kcal} / \mathrm{mol}$; Lovera et al., 1997).

1072 Figure 8: Comparison between our K-Ar ages on biotite and available U-Pb age on zircons.

1074 Figure 9: Comparison of our new $\mathrm{K} / \mathrm{Ar}$ and ${ }^{40} \mathrm{Ar} /{ }^{39} \mathrm{Ar}$ ages on micas and available U-Pb on 1075 zircons (see references in Table 1). The new ages acquired on biotite and muscovite are 1076 shown with black and brown characters, respectively. JPCSZ: Juzbado-Penalva do Castelo 1077 Shear Zone; JPCSZ: Juzbado-Penalva do Castelo Shear Zone ; CBCSZ - Coimbra-Badajoz1078 Cordoba Shear Zone.

Figure 10: Synthetic cartoon showing the successive vertical positions of samples J, X, AC and AS between 300 and $250 \mathrm{Ma}$, as deduced from MDD modelling. Sample 107AS is a granite intruded into the nappes of the GTMZ (after thrusting). F1: main thrust separating the

1083 South Portuguese Zone (SPZ) and the Ossa-Morena Zone (OMZ); F2: Coimbra-Badajoz-

1084 Cordoba Shear Zone (CBCSZ) separating the Ossa-Morena Zone and the Central Iberian 1085 Zone; F3: Juzbado-Penalva do Castelo Shear Zone (JPCSZ). Solid lines indicate inferred 1086 active fault movements at a given time; dotted lines indicate inactive fault movements. In 1087 each structural zone, colored arrows, show the amount of uplift between successive stages. 


\begin{tabular}{|c|c|c|c|c|c|c|c|}
\hline Sample & $\begin{array}{c}\text { Longitude } \\
\left({ }^{\circ}\right)\end{array}$ & $\begin{array}{l}\text { Latitude } \\
\left({ }^{\circ}\right)\end{array}$ & Zone & $\begin{array}{c}\text { Symbol - description on the } \\
\text { geological map }\end{array}$ & $\begin{array}{l}\text { Amount } \\
\text { of strain }\end{array}$ & $\begin{array}{c}\text { Strain type - kinematics } \\
\text { Field data }\end{array}$ & $\begin{array}{l}\text { U-Pb } \\
\text { (Ma) }\end{array}$ \\
\hline 107D & 38.46046 & -7.75290 & OMZ & $\begin{array}{c}\mathrm{pe}_{\mathrm{mg}}-\text { Proterozoic series } \\
\text { migmatized Variscan orogeny }\end{array}$ & +++ & Pervasive steep foliation strike N160 & $\begin{array}{l}577 \pm 10(1) \\
341 \pm 2(2)\end{array}$ \\
\hline $107 \mathrm{G}$ & 38.48016 & -7.64957 & OMZ & $\mathrm{t}-$ orogenic tonalite & ++ & $\begin{array}{l}\text { L-tectonite with lineation strike N170 } \\
\text { Late sinistral strike-slip E-W fault }\end{array}$ & $329 \pm 1(3)$ \\
\hline $107 \mathrm{~J}$ & 38.84073 & -7.89542 & OMZ & $\gamma$-orogenic biotite-rich granite & + & Weak foliation strike N120 & $323 \pm 1(3)$ \\
\hline $107 \mathrm{~K}$ & 39.08173 & -7.41841 & OMZ & $\begin{array}{c}\gamma 3 \text { - late-orogenic biotite-rich } \\
\text { porphyroid granite }\end{array}$ & no & Isotropic & $\begin{array}{l}305 \pm 6(4) \\
301 \pm 5(5)\end{array}$ \\
\hline $107 \mathrm{P}$ & 38.98935 & -7.14817 & OMZ & $\mathrm{T} 1$ - orogenic anorthosite gabbro & no & Isotropic & $305 \pm 6(4)$ \\
\hline $107 \mathrm{~T}$ & 39.41024 & -7.62334 & CIZ & $\begin{array}{l}\gamma 3 \text { - late-orogenic porphyroid } \\
\text { monzonite granite }\end{array}$ & no & Isotropic & $305 \pm 6(4)$ \\
\hline $107 \mathrm{X}$ & 40.17919 & -7.48563 & CIZ & $\begin{array}{c}\gamma \text { II } 2 \mathrm{a}-\text { syn-tectonic quartzdiorite } \\
\text { and biotite granite }\end{array}$ & no & Heavily fractured & $\begin{array}{r}478 \pm 0.5(6) \\
310 \pm 4(7) \\
\end{array}$ \\
\hline 107AC & 40.76379 & -6.85296 & CIZ & $\begin{array}{l}\text { Monzonite granite with sparse } \\
\text { feldspar megacrysts; muscovite } \\
\text { and biotite granite }\end{array}$ & no & Fractured & $303 \pm 7(7)$ \\
\hline 107AH2 & 40.84370 & -7.18323 & CIZ & $\gamma 1 \mathrm{~T}-$ orogenic augen gneiss & +++ & $\begin{array}{c}\text { Pervasive foliation, sub-vertical E-W ductile } \\
\text { shear zone, sinistral kinematics }\end{array}$ & $\begin{array}{c}313-317 \mathrm{Ma} \\
(8,9)\end{array}$ \\
\hline $107 \mathrm{AJ}$ & 40.99665 & -7.47315 & CIZ & $\begin{array}{l}\gamma \mathrm{I} 3 \text { - syn-F3 orogenic 2-mica } \\
\text { granite }\end{array}$ & ++ & $\begin{array}{l}\text { Ductile, sub-vertical foliation N135 (S), N100 } \\
\text { sub-vertical (C), lineation } 15^{\circ}, \mathrm{N} 100 \text {, left-lateral } \\
\text { kinematics }\end{array}$ & $319 \pm 3(10)$ \\
\hline $107 \mathrm{AN}$ & 41.08813 & -7.79960 & CIZ & $\begin{array}{c}\gamma \mathrm{II} 1 \text { - early orogenic biotite } \\
\text { granodiorite }\end{array}$ & ++ & $\begin{array}{c}\text { Ductile, foliation N070, } 55^{\circ} \mathrm{SE} \\
\text { Dykes N015, } 25^{\circ} \mathrm{E} \text { cut by faults } \mathrm{N} 45,55^{\circ} \mathrm{SE} \\
\text { striation } 45^{\circ}, \mathrm{N} 160, \text { normal dextral kinematics } \\
\end{array}$ & $319 \pm 4(11)$ \\
\hline 107AS & 41.50952 & -8.25861 & GTMZ & $\begin{array}{l}\gamma \mathrm{II} 2 \mathrm{~b}(\gamma \mathrm{III} 3 \mathrm{c} ?)-\text { syn-orogenic } \\
\text { porphyroid granite/granodiorite }\end{array}$ & + & $\begin{array}{l}\text { Faults N060 sub-vertical, sinistral strike-slip } \\
\text { Faults N020, sub-vertical, dextral strike-slip }\end{array}$ & $309 \pm 1(11)$ \\
\hline
\end{tabular}

Table 1. Main characteristics of the investigated outcrops and samples. OMZ - Ossa-Morena Zone; CIZ - Central Iberian Zone; GTMZ - Galicia Trás-os-Montes Zone. Symbols and description according to the geological map of Portugal (1/500,000 Geological map of Portugal-LNEG (1992). Zircon U-Pb ages from: (1) Chichorro et al. (2008); (2) Pereira et al. (2015); (3) Lima et al. (2012); (4) Sola et al. (2009); (5) Lopes et al. (2016); (6) Antunes et al. (2012); (7) Neiva et al., 2012; (8) Valle-Aguado et al. (2005); (9) Ferreira et al. (2019); (10) Pereira et al. (2018); (11) Dias et al. (1998). Pre-Variscan ages (inherited zircon) indicated in Italics. Additional information on previous U/Pb ages is provided in 
Table 2. New K-Ar results on the various mineral phases of our samples. Lat.: latitude, Long.: longitude; KFd: K-Feldspar (only one $\mathrm{Ar}$ determination), biot: biotite, musc: muscovite. The mean age is obtained by weighing by the amount of radiogenic argon $\left({ }^{40} \mathrm{Ar} *\right)$, except in the case of 107D-biot, 107G-biot, and 107J-musc; for the latter, all three individual determinations overlap within uncertainties, and the mean age $\left(^{*}\right)$ is calculated by weighing by the inverse of variance. Measured ages in normal font, and mean ages in bold font. Uncertainties quoted at the $1 \sigma$ level.

\begin{tabular}{|c|c|c|c|c|c|c|c|}
\hline Sample & Longitude & Latitude & $\mathrm{K} \%$ & $\begin{array}{c}{ }^{40} \mathrm{Ar} * \\
(\%)\end{array}$ & $\begin{array}{c}{ }^{40} \text { Ar }{ }^{*} \\
\left(10^{15} \text { at.g }^{-1}\right)\end{array}$ & $\begin{array}{l}\text { Age } \\
(\mathbf{M a}) \\
\end{array}$ & $\begin{array}{l}\text { Unc. } \\
\text { (Ma) } \\
\end{array}$ \\
\hline \multirow[t]{4}{*}{ 107D-biot } & -7.75290 & 38.46046 & 7.598 & 98.7 & 2.918 & 334.6 & 4.7 \\
\hline & & & & 99.2 & 2.943 & 337.2 & 4.8 \\
\hline & & & & 97.9 & 2.903 & 333.1 & 4.7 \\
\hline & & & & & mean* & 335.0 & 2.7 \\
\hline \multirow[t]{4}{*}{ 107G-biot } & -7.64957 & 38.48016 & 7.643 & 98.4 & 2.927 & 333.8 & 4.7 \\
\hline & & & & 98.6 & 2.850 & 325.8 & 4.6 \\
\hline & & & & 96.5 & 2.889 & 329.8 & 4.7 \\
\hline & & & & & mean* & 329.7 & 2.7 \\
\hline \multirow[t]{4}{*}{ 107J-biot } & -7.89542 & 38.84073 & 7.471 & 97.3 & 2.722 & 318.9 & 4.5 \\
\hline & & & & 95.7 & 2.619 & 307.8 & 4.4 \\
\hline & & & & 99.3 & 2.663 & 312.5 & 4.4 \\
\hline & & & & & mean & 313.0 & 4.4 \\
\hline \multirow[t]{4}{*}{$107 \mathrm{~J}-\mathrm{musc}$} & -7.89542 & 38.84073 & 8.722 & 97.2 & 3.095 & 311.3 & 4.4 \\
\hline & & & & 98.9 & 3.122 & 313.8 & 4.4 \\
\hline & & & & 98.7 & 3.102 & 311.9 & 4.4 \\
\hline & & & & & mean* & 312.3 & 2.6 \\
\hline \multirow[t]{3}{*}{ 107K-biot } & -7.41841 & 39.08173 & 6.808 & 98.9 & 2.356 & 304.2 & 4.3 \\
\hline & & & & 96.9 & 2.363 & $305 / 0$ & 4.3 \\
\hline & & & & & mean & 304.6 & 4.3 \\
\hline 107J-KFd & -7.89542 & 38.84073 & 10.050 & 94.1 & 3.273 & 287.6 & 4.1 \\
\hline \multirow[t]{3}{*}{ 107P-biot } & -7.14817 & 38.98935 & 7.725 & 98.9 & 2.685 & 305.4 & 4.3 \\
\hline & & & & 98.5 & 2.706 & 307.6 & 4.4 \\
\hline & & & & & mean & 306.5 & 4.3 \\
\hline 107T-KFd & -7.62334 & 39.41024 & 10.890 & 96.3 & 3.319 & 270.5 & 3.8 \\
\hline \multirow[t]{4}{*}{ 107T-biot } & -7.62334 & 39.41024 & 7.494 & 97.8 & 2.549 & 299.4 & 4.2 \\
\hline & & & & 97.5 & 2.509 & 295.1 & 4.2 \\
\hline & & & & & mean & 297.3 & 4.2 \\
\hline & & & & & & & \\
\hline
\end{tabular}




\begin{tabular}{|c|c|c|c|c|c|c|c|}
\hline 107T-musc & -7.62334 & 39.41024 & 7.928 & 98.0 & 2.714 & 301.2 & 4.3 \\
\hline & & & & 98.1 & 2.732 & 303.0 & 4.3 \\
\hline & & & & & mean & 302.1 & 4.3 \\
\hline 107X-KFd & -7.48563 & 40.17919 & 11.308 & 88.0 & 3.355 & 263.8 & 3.7 \\
\hline \multirow{3}{*}{ 107X-biot } & -7.48563 & 40.17919 & 7.692 & 98.9 & 2.492 & 286.3 & 4.1 \\
\hline & & & & 98.6 & 2.533 & 290.6 & 4.1 \\
\hline & & & & & mean & 288.4 & 4.1 \\
\hline 107AC-KFd & -6.85296 & 40.76379 & 8.819 & 96.1 & 2.683 & 270.0 & 3.8 \\
\hline \multirow[t]{3}{*}{ 107AC-biot } & -6.85296 & 40.76379 & 7.335 & 98.0 & 2.491 & 299.0 & 4.2 \\
\hline & & & & 92.2 & 2.464 & 296.0 & 4.2 \\
\hline & & & & & mean & 297.4 & 4.2 \\
\hline \multirow{4}{*}{ 107AC-musc } & -6.85296 & 40.76379 & 8.266 & 97.7 & 2.811 & 299.3 & 4.2 \\
\hline & & & & 95.7 & 2.723 & 290.7 & 4.1 \\
\hline & & & & 98.5 & 2.738 & 292.1 & 4.1 \\
\hline & & & & & mean & 294.0 & 4.2 \\
\hline \multirow[t]{3}{*}{ 107AH2-biot } & -7.18323 & 40.84370 & 7.561 & 97.8 & 2.482 & 289.8 & 4.1 \\
\hline & & & & 98.3 & 2.560 & 298.1 & 4.2 \\
\hline & & & & & mean & 294.0 & 4.2 \\
\hline \multirow[t]{3}{*}{ 107AJ-biot } & -7.47315 & 40.99665 & 7.521 & 99.1 & 2.491 & 292.1 & 4.1 \\
\hline & & & & 98.6 & 2.451 & 287.8 & 4.1 \\
\hline & & & & & mean & 289.9 & 4.1 \\
\hline \multirow[t]{4}{*}{ 107AN-biot } & -7.79960 & 41.08813 & 7.371 & 92.2 & 2.553 & 304.4 & 4.3 \\
\hline & & & & 98.9 & 2.606 & 310.3 & 4.4 \\
\hline & & & & 98.8 & 2.502 & 298.8 & 4.2 \\
\hline & & & & & mean & 304.5 & 4.3 \\
\hline \multirow[t]{3}{*}{ 107AS-biot } & -8.25861 & 41.50952 & 7.640 & 93.4 & 2.691 & 309.1 & 4.4 \\
\hline & & & & 97.9 & 2.671 & 307.1 & 4.4 \\
\hline & & & & & mean & 308.1 & 4.4 \\
\hline
\end{tabular}


Table 3. New ${ }^{40} \mathrm{Ar} /{ }^{39} \mathrm{Ar}$ results on the various mineral phases of our samples. Plateau ages are given with analytical uncertainties, with the total (i.e. including J-factor error) uncertainty in parentheses. $\mathrm{n}$ : number of steps included in the plateau; $\mathrm{N}$ : total number of steps performed. $\%{ }^{39} \mathrm{Ar}$ : cumulative amount of ${ }^{39} \mathrm{Ar}$ included in the plateau. MSWD: mean square weighted deviates. All uncertainties quoted at the $1 \sigma$ level.

\begin{tabular}{|c|c|c|c|c|c|c|}
\hline Sample & $\begin{array}{l}\text { Plateau age } \\
\text { (Ma) }\end{array}$ & $\mathbf{n} / \mathbf{N}$ & $\left(\%{ }^{39} \mathrm{Ar}\right)$ & MSWD & $\begin{array}{c}\text { Integrated } \\
\text { age (Ma) }\end{array}$ & $\begin{array}{l}\text { K-Ar age } \\
\text { (Ma) }\end{array}$ \\
\hline 107J-biot & - & - & - & - & $309.2 \pm 2.9$ & $313.0 \pm 4.4$ \\
\hline 107J-musc & $\begin{array}{c}308.7 \pm 0.2 \\
(2.8)\end{array}$ & $8 / 13$ & 83.8 & 2.1 & $308.8 \pm 3.0$ & $312.2 \pm 2.6$ \\
\hline 107T-biot & $\begin{array}{c}297.1 \pm 0.2 \\
(2.7)\end{array}$ & $4 / 11$ & 52.5 & 1.2 & $295.7 \pm 2.8$ & $297.3 \pm 4.2$ \\
\hline 107T-musc & $\begin{array}{c}297.1 \pm 0.2 \\
(2.8)\end{array}$ & $6 / 14$ & 70.0 & 1.9 & $297.2 \pm 2.8$ & $302.1 \pm 4.3$ \\
\hline 107AC-biot & $\begin{array}{c}296.4 \pm 0.3 \\
(2.7)\end{array}$ & $5 / 13$ & 51.8 & 1.5 & $294.1 \pm 2.8$ & $297.4 \pm 4.2$ \\
\hline 107AC-musc & $\begin{array}{l}294.5 \pm 0.1 \\
(2.7)\end{array}$ & $11 / 15$ & 92.1 & 2.3 & $294.9 \pm 2.8$ & $294.0 \pm 2.4$ \\
\hline 107X-biot & - & - & - & - & $283.7 \pm 2.8$ & $288.4 \pm 4.1$ \\
\hline 107AN-biot & $\begin{array}{c}300.4 \pm 0.2 \\
(2.8)\end{array}$ & $5 / 11$ & 51.8 & 3.0 & $298.6 \pm 2.8$ & $304.5 \pm 4.3$ \\
\hline 107AS - biot & - & - & - & - & $304.2 \pm 2.9$ & $308.1 \pm 4.4$ \\
\hline $107 \mathrm{~J}-\mathrm{KFd}$ & - & - & - & - & $281.0 \pm 2.7$ & $287.6 \pm 4.1 *$ \\
\hline $107 \mathrm{~T}-\mathrm{KFd}$ & - & - & - & - & $272.6 \pm 2.7$ & $270.5 \pm 3.8 *$ \\
\hline $107 \mathrm{X}-\mathrm{KFd}$ & - & - & - & - & $265.6 \pm 2.6$ & $263.8 \pm 3.7 *$ \\
\hline 107AC - KFd & - & - & - & - & $261.0+2.6$ & $270.0 \pm 3.8 *$ \\
\hline $\begin{array}{c}\text { 107AC - } \\
\text { KFd-duplicate }\end{array}$ & - & - & - & - & $261.3 \pm 2.6$ & $270.0 \pm 3.8 *$ \\
\hline 107AS - KFd & - & - & - & - & $292.3 \pm 2.6$ & \\
\hline
\end{tabular}




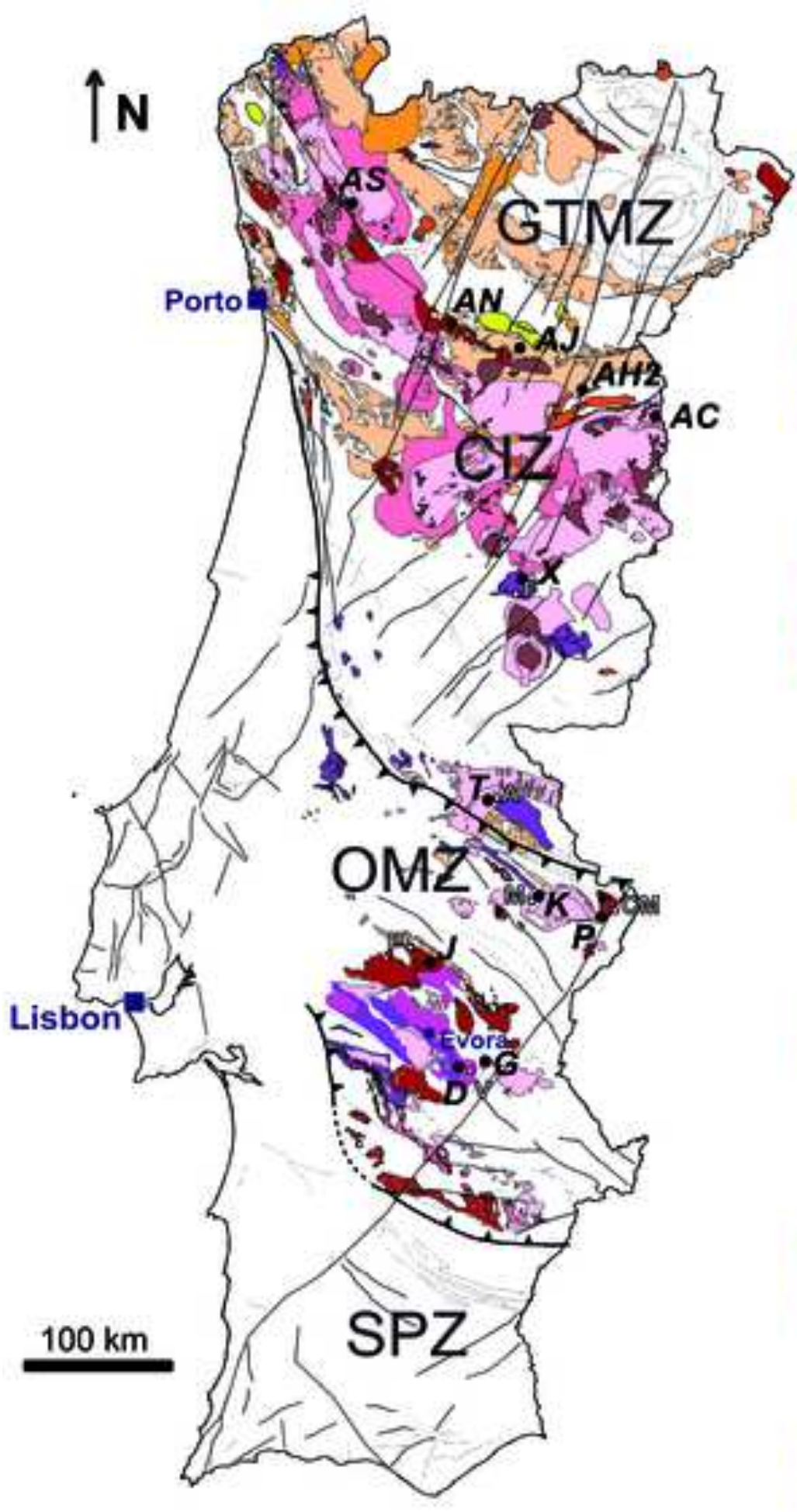

\section{Central Iberian Zone (CIZ)}

Late-to postorogenic rocks

Post-C3 granites

Late- to post-C3

Late-C3 biotite granites (medium to fine grained)

Late-C3 biotite granites (coarse grained)

Late-C3 two mica granites

Synorogenic rocks

Syn-C3 two mica granites

Syn-C3 biotite granites

$\square$ Pre-C3 granites

Pre-orogenic rocks

Pre-orogenic granites

\section{Ossa-Morena Zone (OMZ)}

Late-to postorogenic rocks

Late orogenic granites

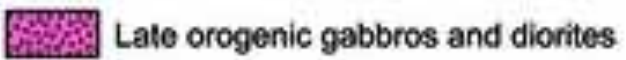

Synorogenic rocks

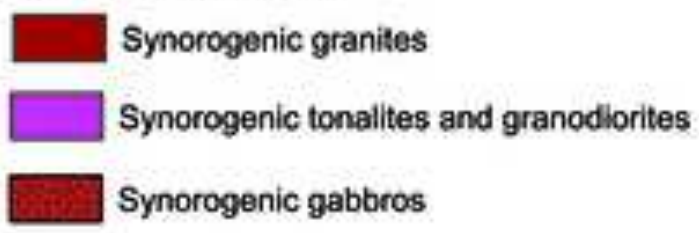

Pre-orogenic rocks

Pre-orogenic orthogneiss

Figure 1: Simplified geological map of Portugal showing the various Variscan and pre-Variscan chronostratigraphic units in the main tectonic zones. The position of our dated samples is reported with black circles. Sample acronyms indicated with bold italic font. SPZ is South Portuguese Zone, and GTMZ is Galicia-Trás-os-Montes Zone. Main towns shown with dark blue solid squares; smaller towns and villages shown with white squares circled with black. A: Alpalhão, CM: Campo Maior, F: Fundão, G: Guimarães, M: Monforte, P: Pavia, V: Vendinha. 


\section{Tectonics Metamorphism Magmatism}

\section{Subduction} Collision

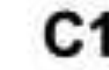

E1

Prograde

Barrovian

to MP-MT

C2

E2
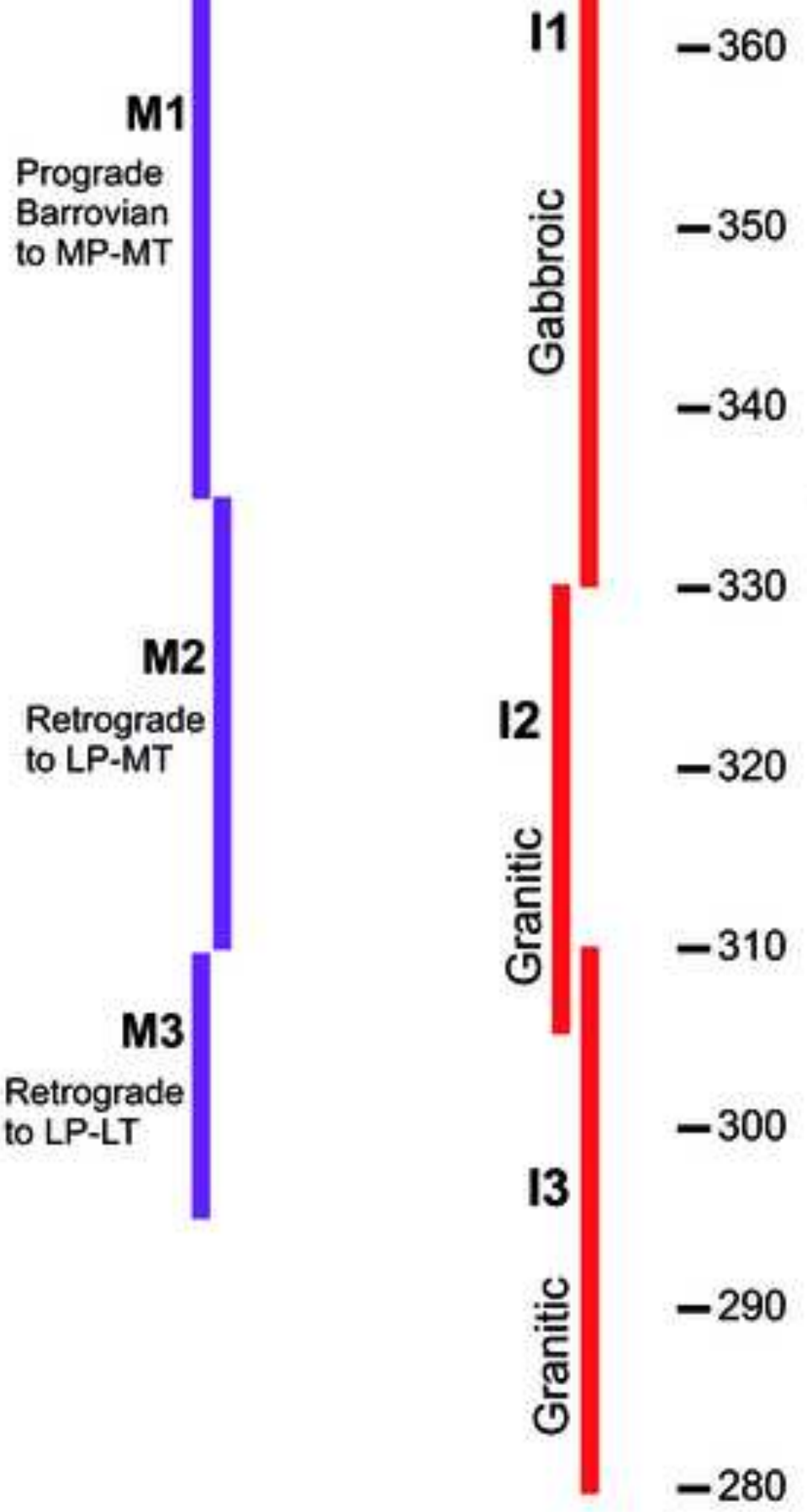

Figure 2: Tectonic/metamorphic/igneous evolution in the CIZ, GTMZ and OMZ. C stands for contractional deformation, E for extensional, M for metamorphic, and I for igneous. II - Syn-kinematic gabbro, granodiorite, and tonalite; I2 - syn-kinematic granite and adamellite; 13 - late- to post-kinematic granitoids. Metamorphic grades, tectonic events, and some of the ages from Martínez Catalán et al. (2014). Subduction to collision age from Moita et al. (2005a, b). 11 ages 360-330 Ma from Dallmeyer et al. (1993), Rosas et al. (2008), Jesus et al. (2007), Pin et al. (2008). 

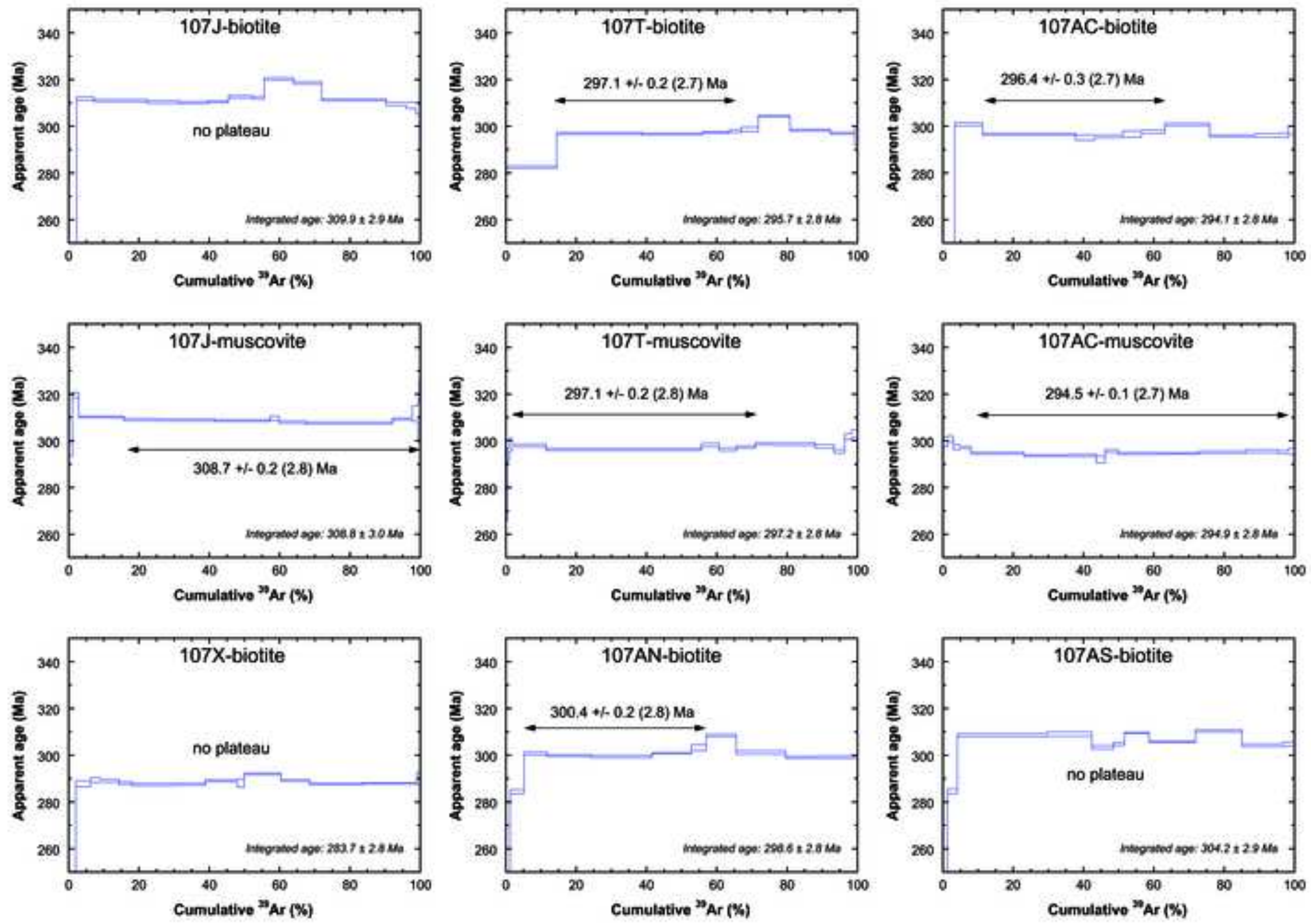

Figure 3: ${ }^{40} \mathrm{Ar} /{ }^{39} \mathrm{Ar}$ age spectra on biotite and muscovite. Plateau ages shown with double arrows. Total age uncertainty in brackets. 


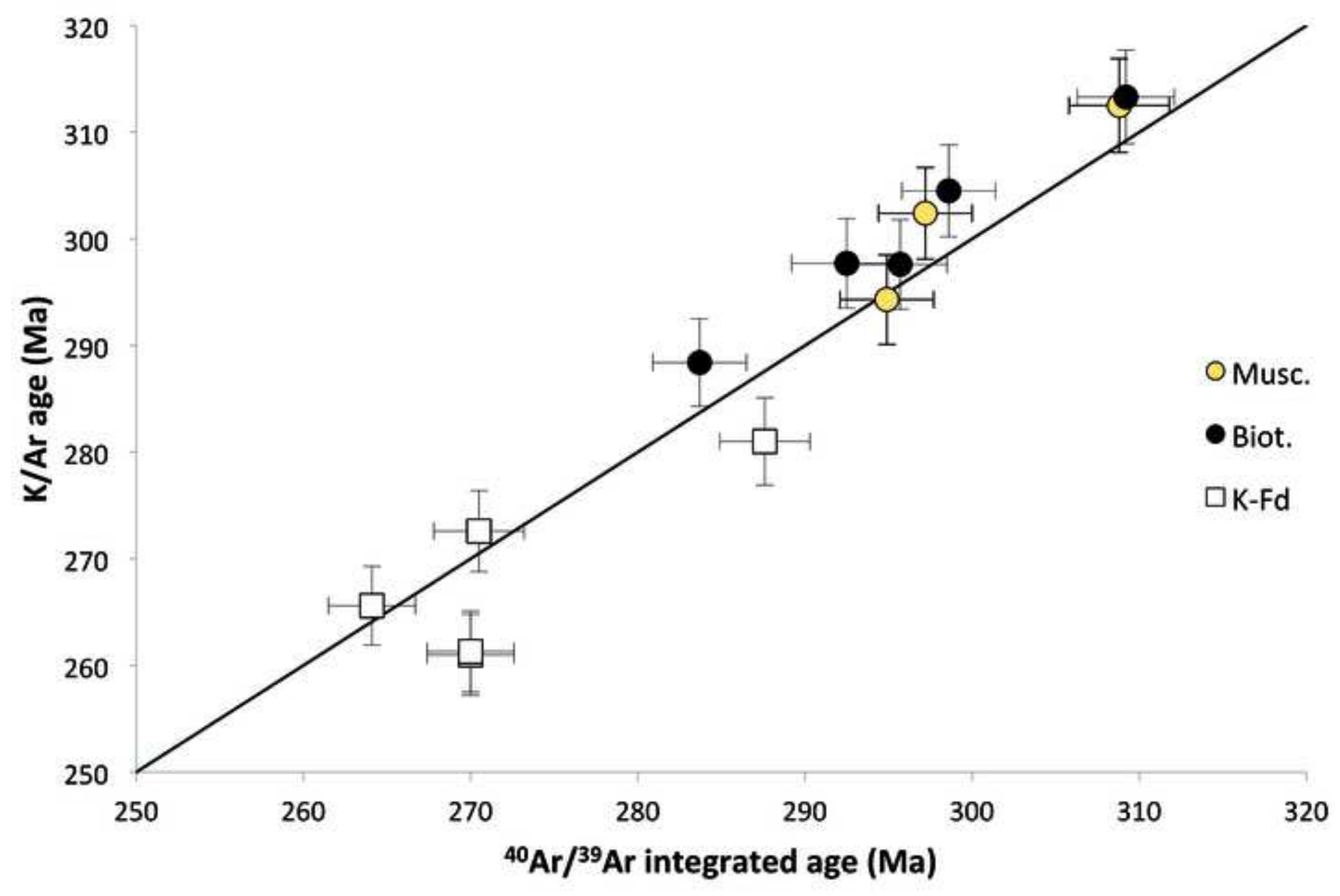

Figure 4: Comparison between our $\mathrm{K}-\mathrm{Ar}$ and ${ }^{40} \mathrm{Ar} /{ }^{39} \mathrm{Ar}$ integrated ages. 

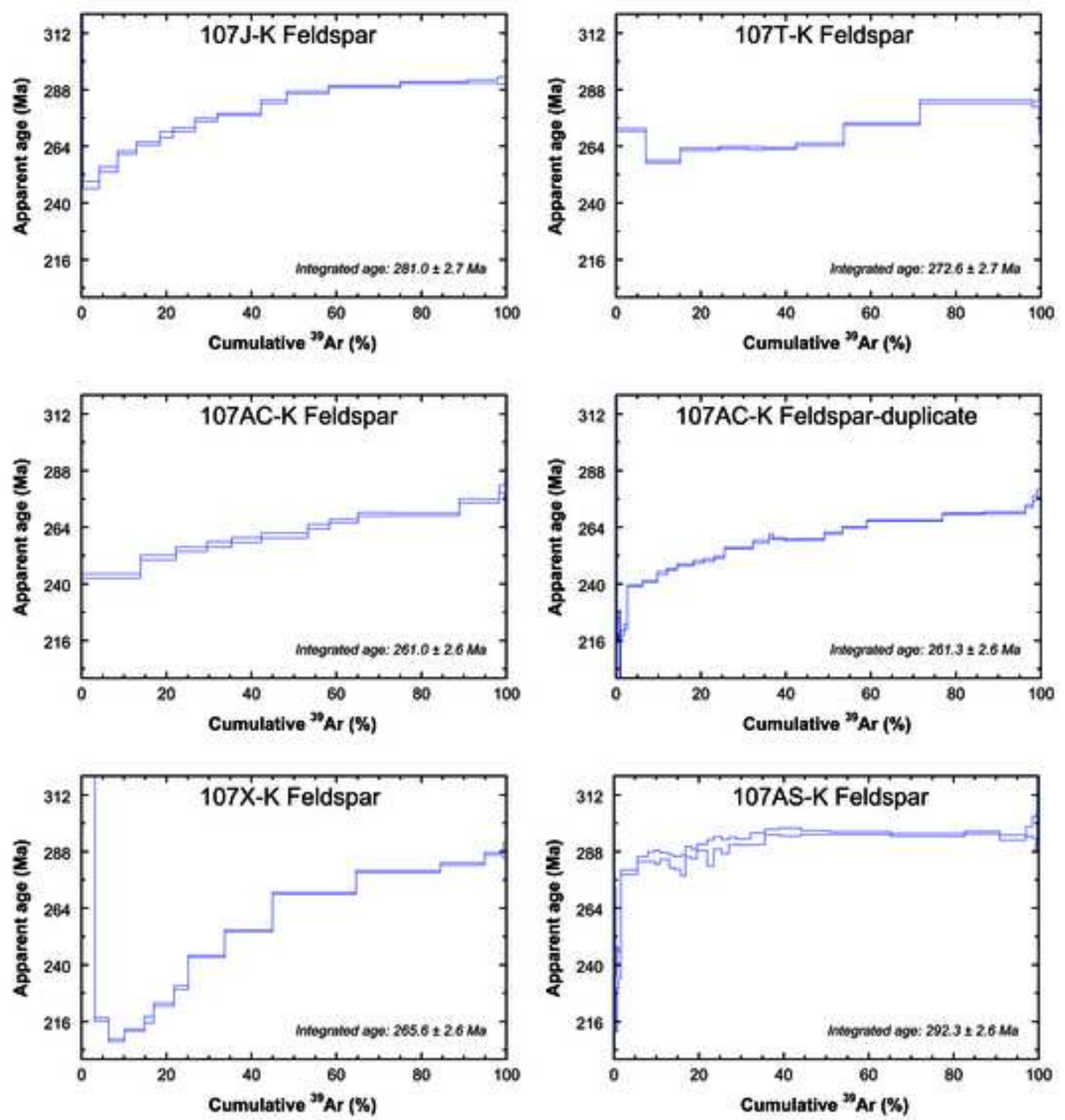

Figure 5: ${ }^{40} \mathrm{Ar} /{ }^{39} \mathrm{Ar}$ age spectra on K-Feldspars of our samples. 


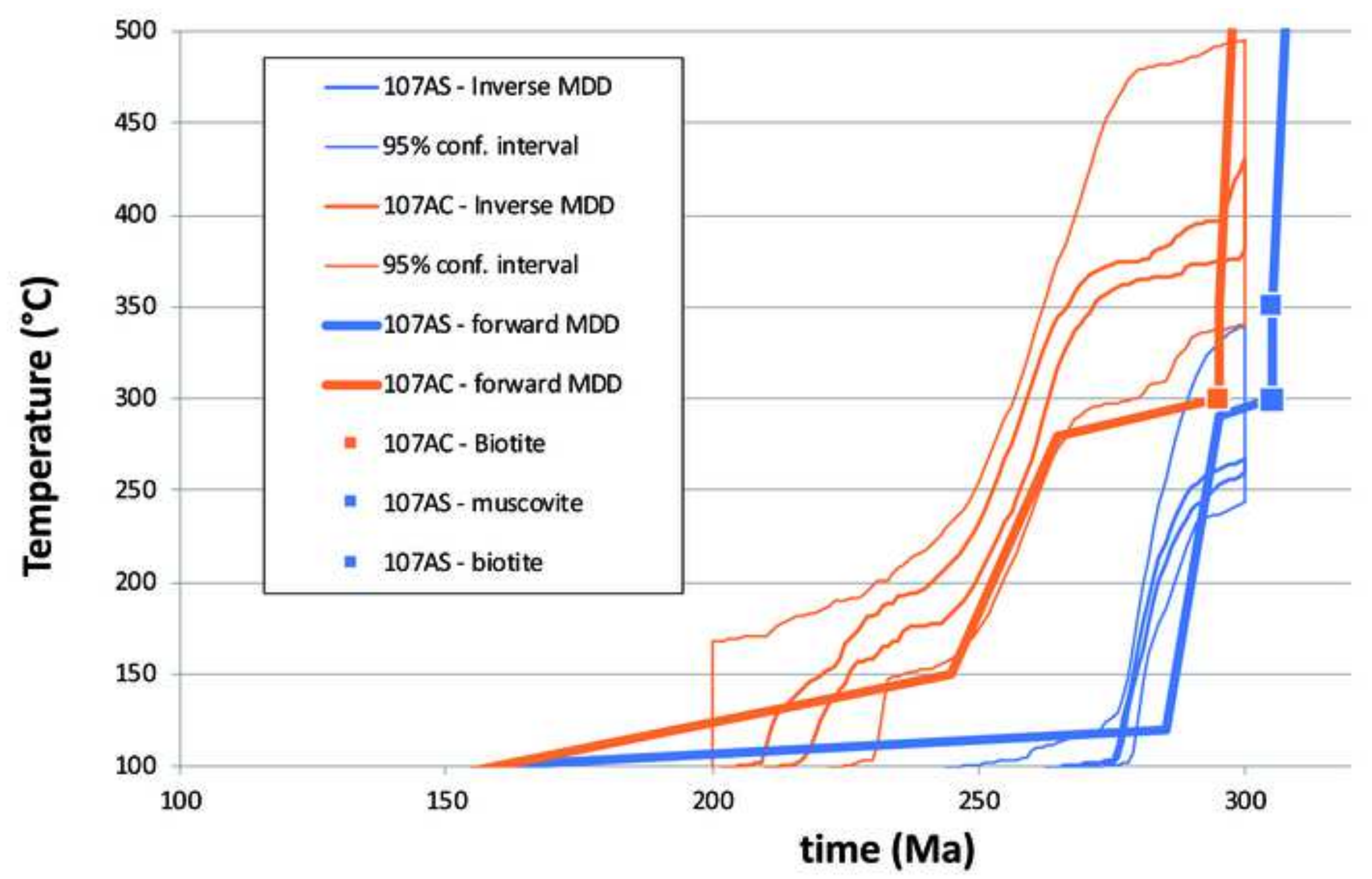

Figure 6: Comparison of thermal histories obtained for samples 107AC and 107AS with MDD inverse and forward modelling (all using an imposed activation energy of $46 \mathrm{kcal} / \mathrm{mol}$, see supplementary figures 1 and 2 for more detail). Note the overall good agreement between inverse and forward modelling for each sample. 


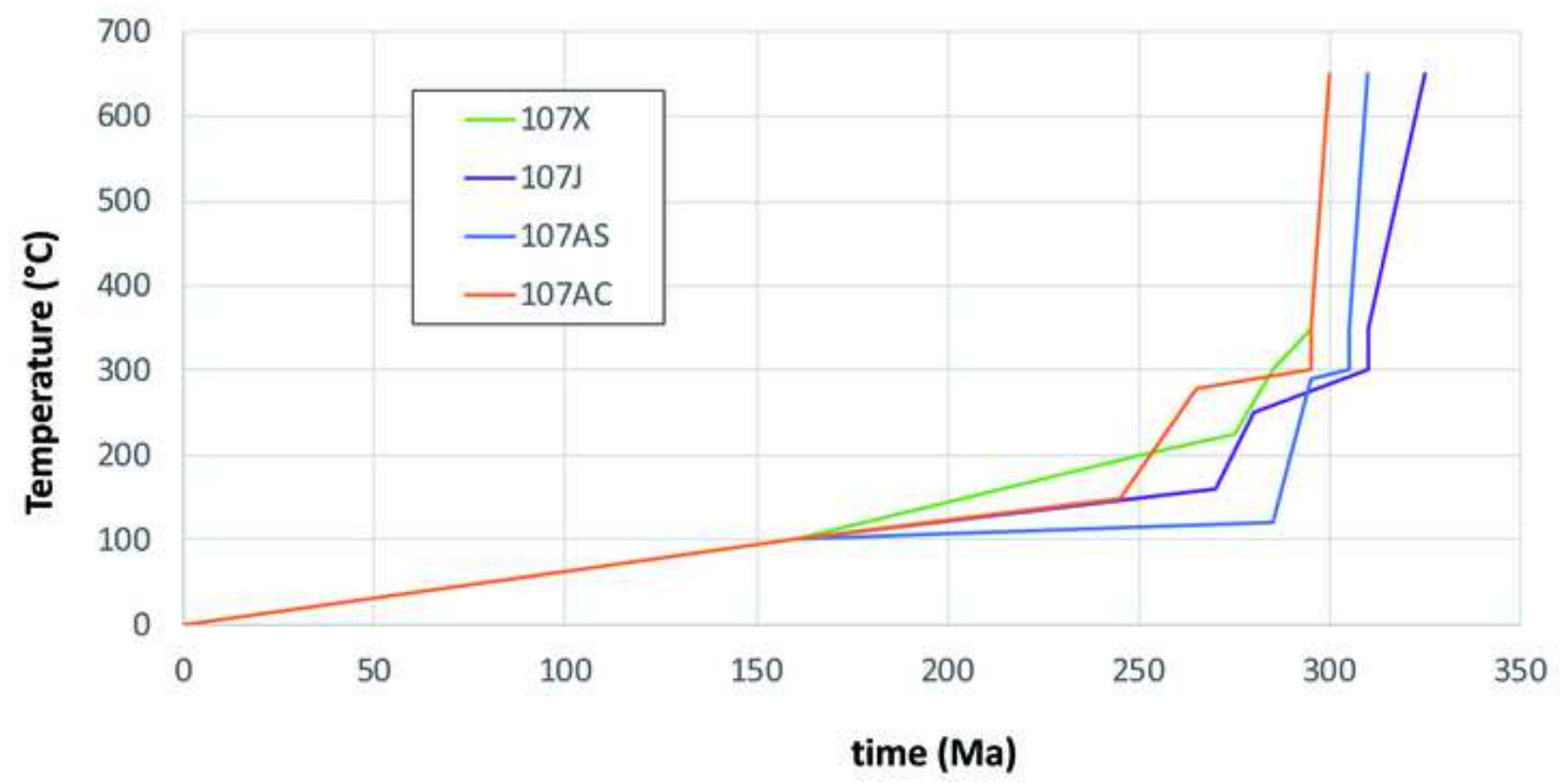

Figure 7: Comparison of the 4 thermal histories obtained with MDD forward modelling on K-Feldspars of our samples 107J, X, AC and AS (all using an imposed activation energy of $46 \mathrm{kcal} / \mathrm{mol}$; Lovera et al., 1997). 


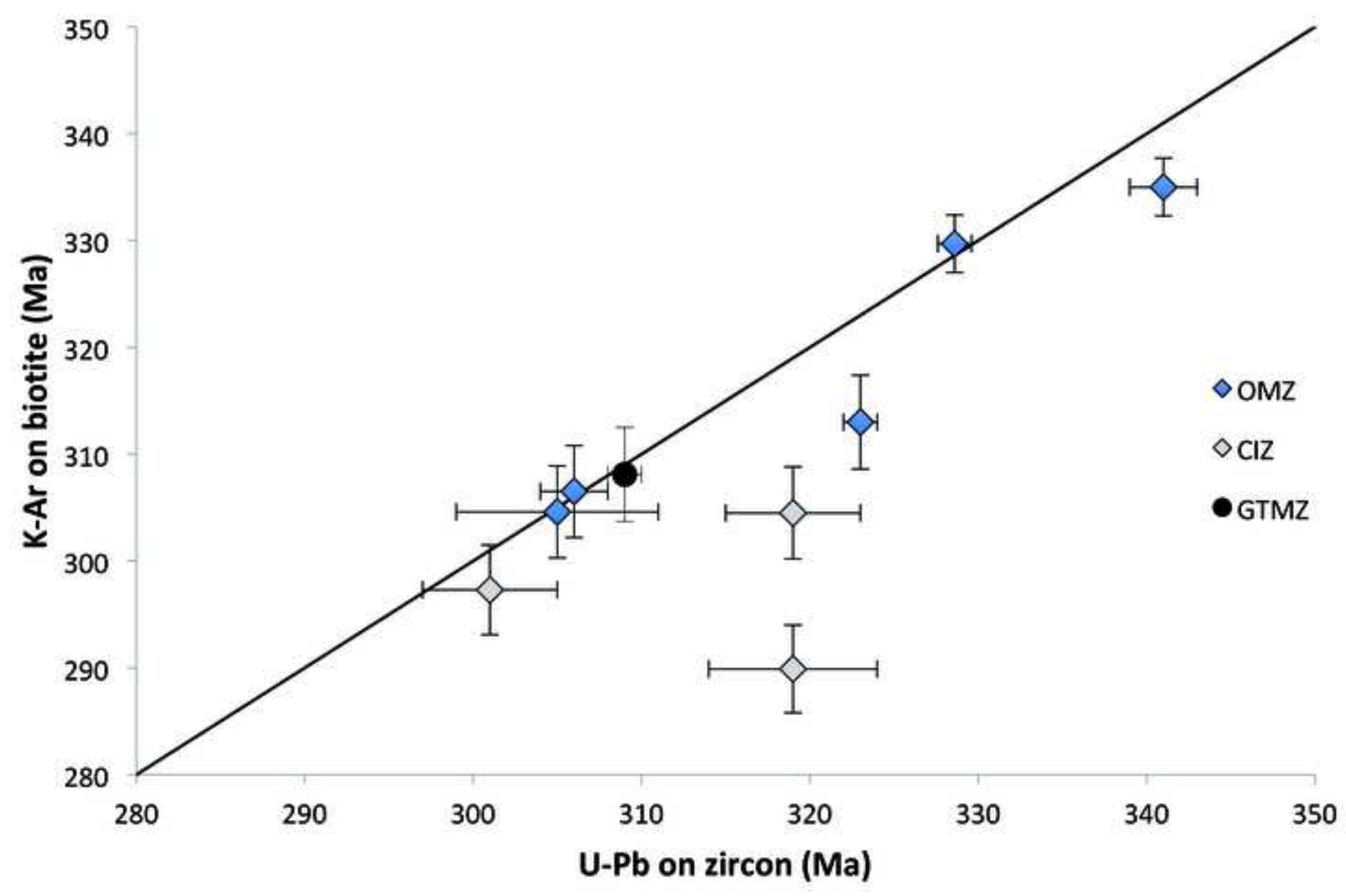

Figure 8: Comparison between our $\mathrm{K}-\mathrm{Ar}$ ages on biotite and available $\mathrm{U}-\mathrm{Pb}$ age on zircons. 


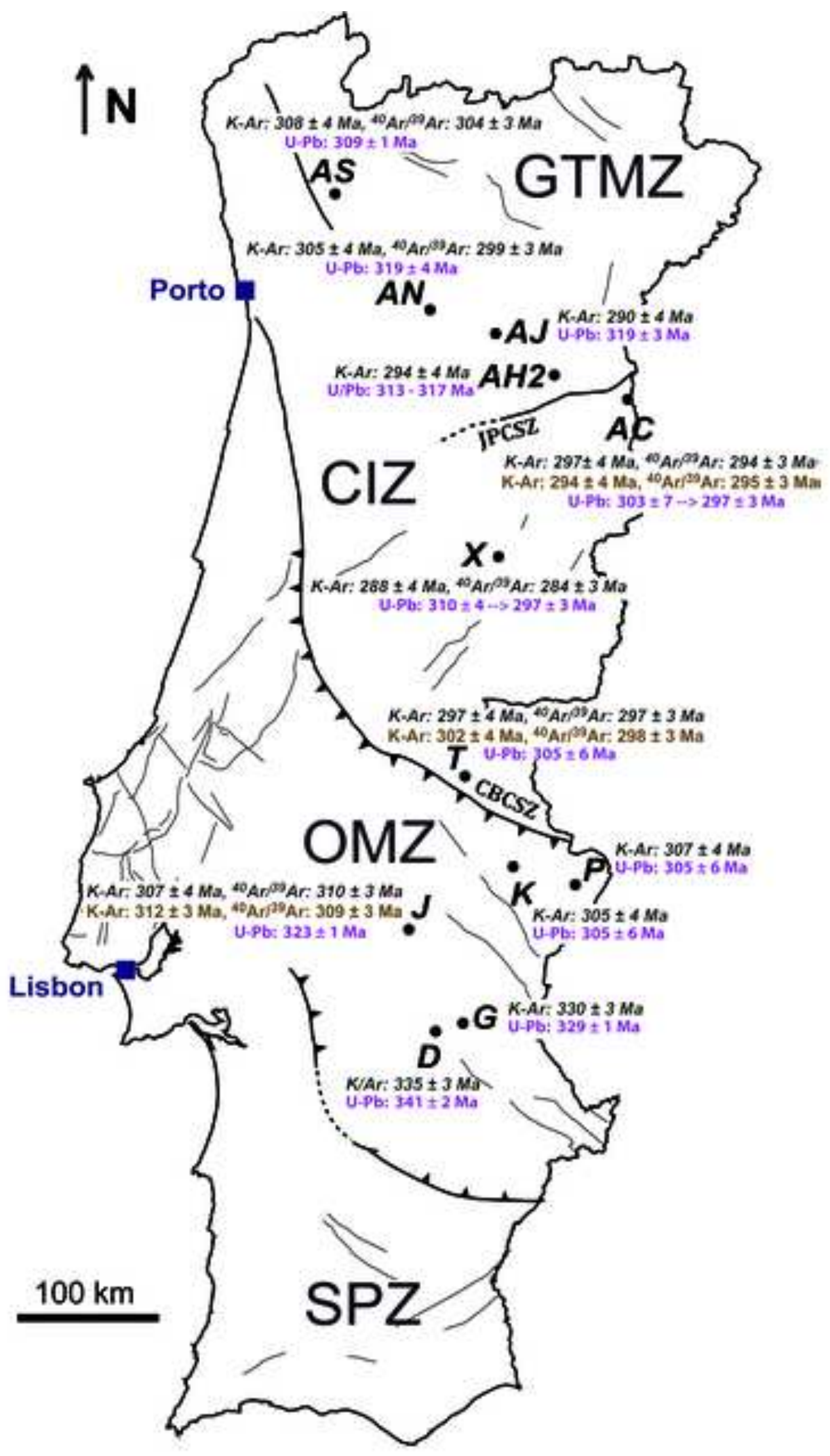

Figure 9: Comparison of our new K/ $\mathrm{Ar}$ and ${ }^{40} \mathrm{Ar} /{ }^{39} \mathrm{Ar}$ ages on micas and available U-Pb on zircons (see references in Table 1). The new ages acquired on biotite and muscovite are shown with black and brown characters, respectively. JPCSZ: Juzbado-Penalva do Castelo Shear Zone; JPCSZ: Juzbado-Penalva do Castelo Shear Zone ; CBCSZ - Coimbra-Badajoz-Cordoba Shear Zone. 

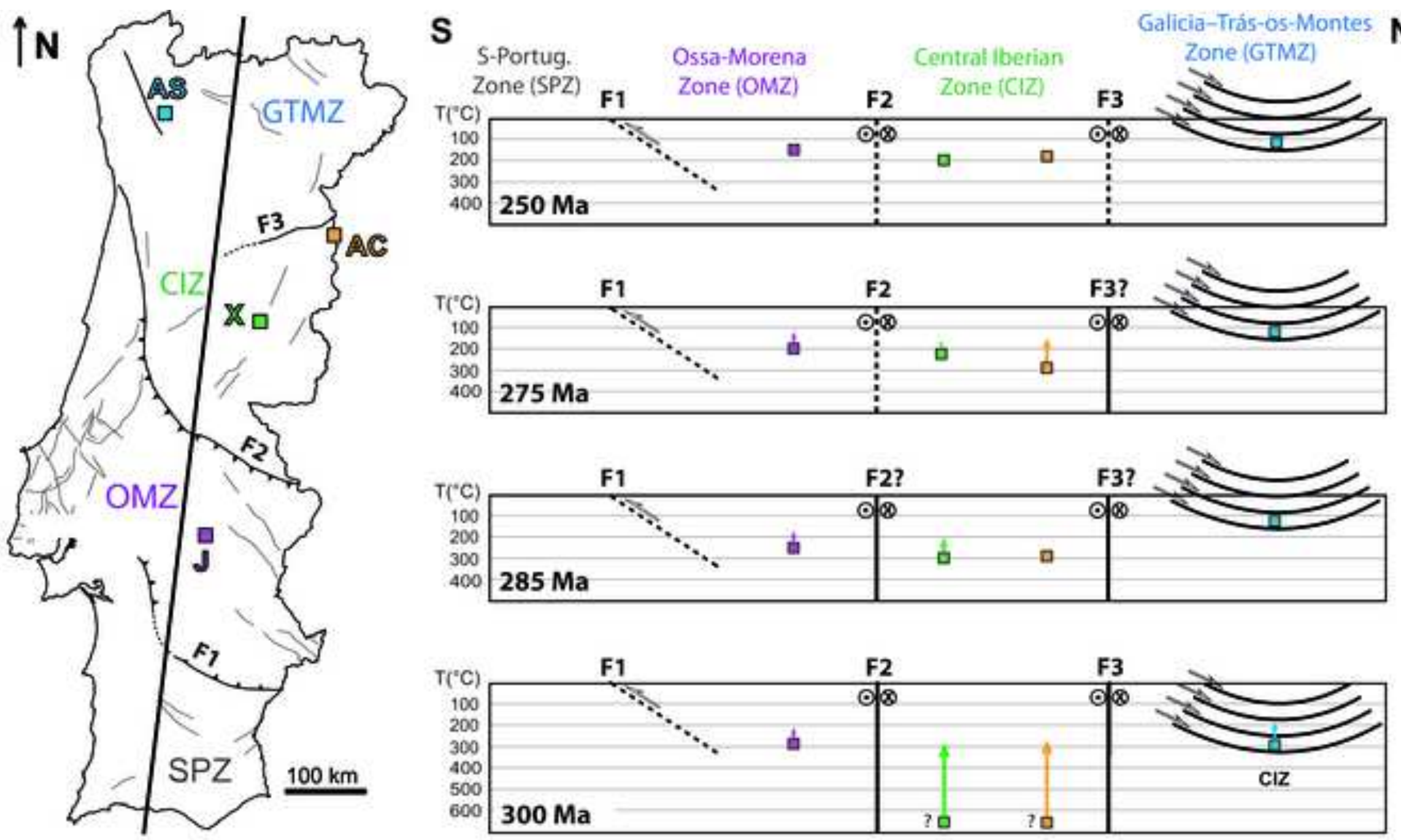

Figure 10: Synthetic cartoon showing the successive vertical positions of samples J, X, AC and AS between 300 and 250 Ma, as deduced from MDD modelling. Sample 107AS is a granite intruded into the nappes of the GTMZ (after thrusting). F1: main thrust separating the South Portuguese Zone (SPZ) and the Ossa-Morena Zone (OMZ); F2: Coimbra-Badajoz-Cordoba Shear Zone (CBCSZ) separating the Ossa-Morena Zone and the Central lberian Zone; F3: Juzbado-Penalva do Castelo Shear Zone (JPCSZ). Solid lines indicate inferred active fault movements at a given time; dotted lines indicate inactive fault movements. In each structural zone, colored arrows, show the amount of uplift between successive stages. 
Click here to access/download Supplementary material for online publication only Hildenbrand et al._Exhumation_IberiaSupplement1.pdf 
Click here to access/download Supplementary material for online publication only Hildenbrand et al._Exhum_Iberia_Suppl-Figs1to5.pdf 
Click here to access/download Supplementary material for online publication only Hildenbrand_Exhumation_Iberia_Suppl2.pdf 


\section{Declaration of interests}

The authors declare that they have no known competing financial interests or personal relationships that could have appeared to influence the work reported in this paper. 


\section{Credit Authors statement}

Anthony Hildenbrand (AH) and Fernando Ornelas Marques (FOM) designed the study. AH and Xavier Quidelleur (XQ) achieved the geochronological and thermochronological analyses. Fernando Noronha (FN) supervised the aspects regarding minearlization processes. All authors (AH, FOM, XQ, FN) contributed to drafting and discussion. 